\title{
Research Needs for Corrosion Control and Prevention in Energy Conservation Systems
}

\author{
E. W. Brooman \\ J. W. Hurwitch \\ Battelle-Columbus Laboratories
}

June 1985

Prepared by Battelle-Columbus Laboratories for Pacific Northwest Laboratory under Contract DE-AC06-76RLO 1830 with the U.S. Department of Energy

Pacific Northwest Laboratory Operated for the U.S. Department of Energy by Battelle Memorial Institute 


\section{DISCLAIMER}

This report was prepared as an account of work sponsored by an agency of the United States Government. Neither the United States Government nor any agency thereof, nor any of their employees, makes any warranty, express or implied, or assumes any legal liability or responsibility for the accuracy, completeness, or usefulness of any information, apparatus, product, or process disclosed, or represents that its use would not infringe privately owned rights. Reference herein to any specific commercial product, process, or service by trade name, trademark, manufacturer, or otherwise, does not necessarily constitute or imply its endorsement, recommendation, or favoring by the United States Government or any agency thereof. The views and opinions of authors expressed herein do not necessarily state or reflect those of the United States Government or any agency thereof.

\section{PACIFIC NORTHWEST LABORATORY} operated by

BATTELLE

for the

UNITED STATES DEPARTMENT OF ENERGY

under Contract DE-AC06-76RLO 1830

\begin{tabular}{|c|c|}
\hline \multicolumn{2}{|c|}{ Printed in the United States of America } \\
\hline & \\
\hline \multicolumn{2}{|c|}{$\begin{array}{l}\text { Available from } \\
\text { tional Technical Information Service }\end{array}$} \\
\hline \multicolumn{2}{|c|}{ United States Department of Commerce } \\
\hline \multicolumn{2}{|c|}{5285 Port Royal Road } \\
\hline \multicolumn{2}{|c|}{ Springfield, Virginia 22161} \\
\hline \multicolumn{2}{|c|}{$\begin{array}{l}\text { NTIS Price Codes } \\
\text { Microfiche A01 }\end{array}$} \\
\hline & \\
\hline \multicolumn{2}{|c|}{ Printed Copy } \\
\hline & \\
\hline Pages & Codes \\
\hline $007-025$ & A02 \\
\hline $026-050$ & A03 \\
\hline $057-075$ & A04 \\
\hline $076-100$ & A.05 \\
\hline $101-125$ & A06 \\
\hline $126-150$ & $\mathrm{~A} 07$ \\
\hline $151-175$ & A0B \\
\hline $176-200$ & $\mathrm{~A} 09$ \\
\hline $201-225$ & A010 \\
\hline $226-250$ & A011 \\
\hline $251-275$ & A012 \\
\hline $276-300$ & A013 \\
\hline
\end{tabular}


RESEARCH NEEDS FOR CORROSION

CONTROL AND PREVENTION IN

ENERGY CONSERVATION SYSTEMS

\author{
E. W. Brooman \\ J. W. Hurwitch \\ Battelle-Columbus Laboratories
}

June 1985

Results of the Workshop

Held in Seattle, Washington

October 29 to November $\}, 1984$

Prepared by Battelle-Columbus Laboratories for Pacific Northwest Laboratory under Contract DE-AC06-76RL0 1830 with the U.S. Department of Energy under Agreement B-F6814-A-K

Pacific Northwest Laboratory

Richland, Washington 99352 



\section{EXECUTIVE SUMMARY}

\section{BACKGROUND TO PROBLEM}

In the United States of America approximately 4 percent of the Gross Vational Product each year is lost due to corrosion and its effect: . For example, in 3982 the cost of corrosion was about $\$ 122$ billiol, of which close to $\$ 17$ billion could have been avoided by using the best available technology. The opportunity for greater savings exist if riew or improved corrosion control and prevention measures could be implemented. The rationale for spending funds on corrosion related researah and development activities is easily understood in terms of the dollar savings in energy and materials to reduce excess capacity, replace lost product, lower maintenance costs, improve safety, and all the otner factors influenced by corrosion.

To place the problem in perspective, it is of interest to review some of the 1982 estimates for corrosion in America, along with estimates of the avoidable costs:

\begin{tabular}{|c|c|c|c|}
\hline Sector & Cost, $\$ 10^{6}$ & $\begin{array}{l}\text { Avoidable } \\
\text { Cost, } \$ 10^{6}\end{array}$ & $\begin{array}{c}\text { Potential } \\
\text { Saving in Quads }\end{array}$ \\
\hline Energy Industries & 67,500 & 1,360 & 0.26 \\
\hline Electric Power Generation & 6,600 & 210 & 0.04 \\
\hline Materials Production & 13,900 & 370 & 0.07 \\
\hline Government Dperations & 17,800 & 4,500 & 0.87 \\
\hline Aut omobiles (Personally owned) & 16,200 & 10,500 & 2.03 \\
\hline & 122,000 & 16,940 & 3.27 . \\
\hline
\end{tabular}

These data were taken from Report No. 5 listed in the Bibliography of this report. In calculating the savings in equivalent energy in ouads it was assumed that $5.8 \times 10^{6}$ Btu were equivalent to 1 barrel of petroleum and a barrel cost $\$ 30$. A savings of 3.3 quads is equivalent to about 14 percert of the total electrical energy produced in the U.S.A. 


\section{WORKSHOP OBJECTIVES AND FORMAT}

A group of 28 electrochemists, materials scientists and corrosion engineers was brought together in a workshop format to (1) determine if the Government could perform a useful role as a focal point for corrosion R\&D, (2) discuss opportunities in fundamental research and how the results could be applied to solving corrosion problems, and (3) develop a research agenda, if possible, for corrosion research that could have significant impact on energy or materials conservation.

Following an introductory session in which some of the key problems and research in progress in the buildings and structures, transportation and industria? sectors were reviewed by guest speakers, the participants from government, industry and academia assembled into four technical discussion groups. Each group leader had the responsibility for addressing one of the following topics (1) localized corrosion, (2) general corrosion, (3) high temperature corrosion, and (4) corrosion control and prevention. Research needs were identified, discussed, then assigned a figure of merit in terms of their relevancy, urgency, feasibility and impact. Later the results from the four groups were integrated, and the findinas are presented in this report.

\section{WORKSHOP FINDINGS}

Some 44 corrosion control and prevention topics were identified as having a high priority for consideration for funding. Another 35 topics were identified as having a medium priority for funding.

When classified according to corrosion phenomenon, the areas which should receive the most attention are molten salt attack, crevice corrosion, stress-corrosion cracking, erosion-corrosion, pitting attack, intergranuiar attack and corrosion fatigue. When classified according to the sector or system involved, those which should receive the most attention are chemical processes, transportation, buitdings and structures, electric power generation, and batteries and fue? cells. 
A common theme among the discussion groups was the apparent need to establish data bases for specific corrosion phenomena, then make the information available to the designers, engineers and researchers so that they could incorporate the data into products and processes. This type of research need consistently was rated as falling in the high priority category. Eventually, expert systems that could be used with CAD/CAM facilities at the design stage should be developed. To accomplish this nore work would have to be done on modelling corrosion phenomena, and interactions between materials and the environment. The work recentiy initiated by the National Bureau of Standards was cited as an example of the types of data base needed and the useful output that could be generated.

Specific topics that also received the highest fiqures of merit durinc: the screening sessions were as follows:

- Obtain a better understanding of the mechanism(s) of crevice corrosion.

- Study the effects of minor impurities on interaranular corrosion.

- Conduct additional fundamental studies of the corrosion of steel in concrete, including the roles of stress and fatigue.

- Study mechanism(s) of molten salt corrosion in chemical and electrometallurgical processes.

- Evaluate existing and new alloys for their resistance to corrosion fatique, and study the role of aggressive anions.

- Evaluate the use of anodic protection for oreventing or controlling stress-corrosion cracking.

- Study stress-corrosion cracking of Alloy 600 in pressurized water reactor applications.

- Obtain a better understanding of localized solution chemistry in crevice corrosion.

- Study mechanism(s) of molten salt corrosion in heat engines, heaters and heat pipes. 
- Develop alloys which conserve strategic materials and increase the use of ferritic and martensitic stainless steels.

- Study mechanism(s) of molten salt corrosion in batteries and fuel cells.

- Devejop new instruments and non-destructive testing methods to detect corrosion.

- Expand the use of anodic protection to control microbiological corrosion.

- Develop criteria for cathodically protecting specific structures, such as bridge decks.

- Improve alloys and coatings to resist molten salt corrosion in heat engines, heaters and heat pipes.

- Develop a mode? to predict stress-corrosion cracking and apply to problems in sour gas wells.

- Improve alloys and coatings to resist molten salt corrosion in chemical process and electrometallurgical industries.

- Conduct more fundamental studies on automobile corrosion and protection methods.

- Solve the problem of intergranular corrosion of gas diffusion electrodes.

- Develop pore-free titanium coatings for dimensionally stable anodes.

- Develop models and better experimental techniques to study pitting corrosion of a Tuminum.

- Determine mechanisms of intergranular attack and obtain better performance data on the intergranular corrosion of Inconel (a) titanium and aluminum.

- Develop materials resistant to more than one form of attack.

- Investigate effect of surface modification by alloying on crevice corrosion.

(a) A trademark of Nickel Company of New York. 
- Modify processes to restrict contact between liquid metals and refractories and develop improved refractories.

- DeveTop materials and coatings to resist erosioncorrosion in heat engines and chemical process equipment.

- Find less corrosive de-icers for highway use.

- Study effects of trace contaminants on cracking phenomena and develop methods for their removal.

- Develop electrochemical instrumentation for failure analysis and detection.

The above ideas were taken from Table 1 of the report, and are not 1 isted in orcer of their importance.

Two of the inportant areas identified for funding consideration, in terms of the size of the cost savings which would result if R\&D efforts were successful, were the corrosion of steel in concrete and the corrosion of automobiles (as well as other vehicles). A common link between these two is the agressive role the chloride ion plays, because salt is used as a ceicer, and the alternate wetting and drying (or freezing and thawing) of surfaces accessible to the chloride solutions.

Another important area included high temperature oxidation, erosion-corrosion, molten salt and liquid metal attack. With the first three topics especially, degradation occurs through the breakdown of coatirigs under complex conditions. Additional work needs to be done on investigating these simultaneous reactions that occur in electricity generating equipment and electrometallurgical processes.

It is recommended that the DOE consider funding R\&D in the area uf corrosion control and prevention for eneray conservation systerns, and provide funding or support for the establishment of data bases and technology transfer. Initially a modest budget is recormended, and programs should be selected on the basis of the screening criteria used in this report, but also taking into consideration the availability of financial resources in the various sectors. For example, corrosion 
control and prevention methods have received much attention in the electricity generation and automobile industries. The Electric Power Research Institute exists in the former to sponsor research. However, in other industries, such as the chlor-alkali industry and the pulp and paper industry, there are opportunities for solving major corrosion problems, and thereby conserving energy and materials, but the resources are 1 imited. This is particularly true in the former case where production is relatively low and prices are depressed. It is the latter circumstances where the DOE can provide the incentive for conducting the research, particularly when there is a high risk associated with obtaining the desired objectives.

The DOE also can play a supportive role by developing instrumental techniques and testing methodologies, which can be applied to a wide range of corrosion related problems, or by focussing on very specific areas, such as molten salt/liquid metal corrosion, and providing a broader perspective to the problem. 
TABLE OF CONTENTS

Page

EXECUTIVE SUMMARY. . . . . . . . . . . . . . . . . . . . i i

BACKGROUND TO PROBLEM ................... i i

WORKSHOP OBJECTIVES AND FORMAT. . . . . . . . . . . iv

WDRKSHOP FINDINGS .................. iv

INTRODJCTION AND OBJECTIVES. . . . . . . . . . . . . . . . . I

Workshop Objectives . . . . . . . . . . . . . . . 2

Workshop Format. . . . . . . . . . . . . . . . . . 3

IMPACT OF CORROSION ON ENERGY AND MATERIALS CONSERVATION . . . 4

Corrosion of Buildings and Structures.......... 5

Corrosion Problems in Transportation Systems. . . . . . . 7

Corrosion Problems in the Electric Power Industry. . . . 9

Corrosion in Non-Utility Electricity Production Systems . . 12

Corrosion in the Primary Metals Industry. . . . . . . . 14

Corrosion in Industrial Chemical and Gases Industry . . . 16

TECHNICAL DISCUSSION GROUP FINDINGS. . . . . . . . . . . . 19

General Corrosion . . . . . . . . . . . . . . 20

Buildings and Structures............. 20

Transportation . . . . . . . . . . . . . 22

Energy Generation, Distribution and Storage. . . . . 23

Other Industries................ 25

Localized Corrosion ............... . . 25 
$\frac{\text { TABLE OF CONTENTS }}{\text { (Continued) }}$

Page

Stress-Corrosion Cracking. . . . . . . . . . 26

Pitting Attack. . . . . . . . . . . . 27

Crevice Corrosion. . . . . . . . . . . 29

Filiform Corrosion............ 29

Intergranular Corrosion. . . . . . . . 30

Corrosion Fatigue............... 31

Erosion-Corrosion and Cavitation ........ 32

High Temperature Corrosion. . . . . . . . . . . 32

Heat Engines and Related Systems . . . . . . . 33

Chemical Processes............. 35

Batteries and Fuel Cells--High Temperature . . . . 38

Electrometallurgical Processes......... 39

Other Systems--High Temperature. . . . . . . . . 40 40

Corrosion Control and Prevention. . . . . . . . . . 42

Materials. . . . . . . . . . . . . 42

Coatings .............. 43

Design ................ . . . . . 44

Monitoring . . . . . . . . . . . . 44

Environmental Control. . . . . . . . . . 45

Electrochemical Protection Methods ........ 45

Technology Transfer. . . . . . . . . . . . 45 


\title{
TABLE OF CONTENTS \\ (Continued)
}

\begin{abstract}
Page
PRIORITIZED RESEARCH NEEDS . . . . . . . . . . . . . . 46

Screening Procedures. . . . . . . . . . . . . . . 46

Fanking of Research Needs. . . . . . . . . . . . . . 48

General Corrosion............... . . 48

Localized Corrosion. . . . . . . . . . . . 48

High Temperature Corrosion . . . . . . . . . . 48

Corrosion Control and Prevention .......... 48

Prioritization of Research Needs. . . . . . . . . . . 49

CONCLIJSIONS. ..................... 50

Anodic and Cathodic Protection. . . . . . . . . . . 60

Sarburization................. . . . 61

Cavitation. . . . . . . . . . . . . 6 ?

Coatings. . . . . . . . . . . . . . 6 ]

Corrosion Fatigue ................. . . . 62

Crevice Corrosion . . . . . . . . . . . . . . 62

Erosion-Corrosion . . . . . . . . . . . . . 63

Exfoliation and Intergranular Attack. . . . . . . . . . 64

Liquid Metal Attack. . . . . . . . . . . . . . 64

Molten Salt Attack. ................. 64

Pitting Attack. . . . . . . . . . . . . . . . . 65

Strategic Materials Substitution. . . . . . . . . 65

Stress-Corrosion Cracking . . . . . . . . . . . . 66
\end{abstract}


TABLE OF CONTENTS

(Continued)

Page

Tests and Instrumentation . . . . . . . . . . . 66

General Corrosion ................. 67

Corrosion Data Base................. 67

Recommendations.................. 68

ACKNOWLEDGMENTS. . . . . . . . . . . . . . . . . . . 70

BIBL IOGRAPHY . . . . . . . . . . . . . . . . . . . 71

APPENDIX A

WORKSHOP ORGANIZING COMMITTEE AND LIAISON MEMBERS. . . . . . . A- 1

APPENDIX B

LIST OF WORKSHOP PARTICIPANTS AND TECHNICAL GROUP ASSIGNMENTS. - B-?

APPENDIX C

WORKSHOP AGENDA. . . . . . . . . . . . . . . . . C-1

APPENDIX D

RANKING OF RESEARCH NEEDS. . . . . . . . . . . . . . . . . D-1

\section{List of Tabies}

Table 1. Research Needs Considered to have the Highest

Priority for Funding . . . . . . . . . . . . . 51

Table 2. Research Needs Considered to have the Medium

Priority for Funding . . . . . . . . . . . . . . . 55

Tabie 3. Prioritized Research Needs Listed According

to Corrosion Phenomena Involved. . . . . . . . . . 58 


\section{TABLE OF CONTENTS}

(Continued)

Page

$$
\text { List of Tables }
$$

(Continued)

Table 4. Prioritized Research Needs Listed According

to Principal Sector or System Involved....... . 59

Table D-1. Ranking of Research Needs--General Corrosion

Discussion Group . . . . . . . . . . . . D-1

Table D-2. Ranking of Research Needs--Localized Corrosion

Discussion Group............. . . D-2

Table D-3. Ranking of Research Needs--High Temperature

Corrosion Discussion Group . . . . . . . . . . D-5

Table D-4. Ranking of Research Needs--Corrosion Control and Prevention Discussion Group. . . . . . . . D-10 

FINAL REPORT

on

RESEARCH NEEDS FOR CORROSION CONTROL

AND PREVENTION IN ENEYGY CONSERVATION SYSTEMS

to

U.S. DEPARTMENT OF ENERGY

ASSISTANT SECRETARY FOR CONSERVATION AND RENEWABLE ENERGY

DIVISION OF ENERGY STORAGE

from

BATTELLE

Columbus Laboratories

February, 1985

\section{INTRODUCTION AND OBJECTIVES}

The costs of corrosion in the Inited States and throughout the world has been well documented in reports by the National Bureau of Standards, National Association of Corrosion Engineers, and the Department of Energy. Estimates of avoidable cost savings using currently available technology range as high as $\$ 16.9$ billion (in 1982 this dollar amount is equivalent* to 3.3 Quads of energy; or about 14 percent of the total electrical energy produced in the U.S.A.). An aggressive research progran could lead to significantly higher potential savings by making new or better corrosion control or prevention technology available.

The Department of Energy (DOE) has recognized the vast potential savings that improved corrosion prevention could offer. Such savings relate to energy and materials, as well as dollars. A

*Assumes $\$ 30 / 8 b 1$ oil price and $5.8 \times 106 \mathrm{Btu} / \mathrm{Bb}$ of petroleum. 
significant program of fundamental research on various aspects of corrosion has been supported by the Office of Basic Energy Science in the Division of Materiais Sciences. Most of this research, however, is in the very early stages and is not focused on specific applications. The Division of Energy Storage (STOR) under the Assistant Secretary for Conservation and Renewable Energy has as its primary mission the development of energy storage systems for use in transportation, buildings, industrial, and electricity transmission and distribution systems. In this mission STOR is developing advanced battery systems for potential use in electric vehicles and for electric utility load leveling. Corrosion is a serious life-limiting problem in these battery systems. Therefore, corrosion prevention research encompasses a significant portion of the applied research in this program.

The electrochemists, materials scientists, and corrosion engineers assembled to address corrosion problems in advanced battery systems represent a formidable team to solve problems in a broader range of systems. Additionally, the organizational position of STOR makes it well suited to address problems in other Conservation and Renewable Energy systems. It is for this reason that the Division of Energy Storage decided to assemble some of the leading experts in the corrosion field to determine research areas which could offer solutions to corrosion problems in energy conservation systems.

\section{Workshop Objectives}

The objectives of the workshop, as envisioned by the Department of Energy, were to: (1) determine if the Government can perform a useful role as a focal point for corrosion R\&D; (2) bring together electrochemists, materials scientists, and carrosion engineers to discuss fundamental research and how it $c$ an be applied to corrosion problems; and (3) develop an agenda for corrosion research that can have significant impact on energy or materials conservation. 
Workshop Format

The workshop, entitled "Research Needs for Corrosion Control and Prevention in Energy Conservation Systems", was held on 0ctober 29 to November 1, 1984, at the Battelle Seattle Research Center in Seattle, Washington. Twenty-ejght (28) participants representing a cross-section of indistry, government, and academia attended the meeting with the purpose of developing a prioritized research agenda to address corrosion problems in energy conservation systems for consideration by the DOE.

An organizing committee was selected during June, 1984 to pian the workshop. In addition, a liaison committee was identified so that the Department of Energy, National Academy of Sciences, Nationa? Bureau of Standards, and the National Science Foundation could be kept abreast of activities and findings. The list of these individuals can be found in Appindix $A$.

The meeting began with talks from the workshop chairman, cochairm.an, and DOE sponsor so that the background and a sense of mission were conveyed to the participants. Participants were encouraged to interact not only in formal sessions, but also informally during breaks, social functions, and throughout the evenings. Topics highighted for discussion included materials problems, materials properties, interaction of materials with different environments, process modification, testing and instrumentation, and control and prevention.

six presentations followed that surveyed corrosion problems in the areas of transportation; buildings and structures; and industrial applications including electric power, primary metals, chemicals and gases, and other non-utility electricity production systems. These presentations were all completed during the morning of the first day. A brief summary of each of these talks is given in the following section.

The workshop moved into its technical group discussion phase during the afternoon of the first day and continued throughout the morning of the second day. Four technical discussion groups were organized, and each discussion group contained six menbers. The topics of the discussion groups were high-temperature corrosion, general lowtemperature) corrosion, localized corrosion, and corrosion prevention 
and control. Participants in each discussion group can be found in Appendix $B$.

Each discussion group spent several hours getting acquainted and reviewing research ideas and concepts to address corrosion problems that were jdentified during the introductory session. Toward the end of the technical group discussions, each group leader was requested to form a consensus by asking participants to prioritize their ideas in terms of contribution of the research need to the corrosion technology base, probability of success, energy or materials conservation impact, and whether the impact would be Tong, mid, or near term.

The final session was devoted to reviewing the individual technical discussion group lists and discussing a research plan. Froup leaders discussed important issues which cane up throughout the ir daylong discussions, and these were later integrated into this final report by the workshop chairman and co-chairman. The assimilation of all of this information into this report reflects the findings of the workshop participants.

\section{IMPACT OF CORROSION ON ENERGY AND \\ MATERIALS CONSERVATION}

Corrosion problems and their potential impact on energy and materials conservation were discussed in preliminary talks during the first session of the workshop. After an overview talk discussing the cost of corrosion in the United States by Dr. Landgrebe*, six talks addressing corrosion problems in specific areas were given. These areas were:

- Building and Structures

- Transportation Systems

- Electric Power Industry

*Based on the report by Prof. R. E. Meredith entitied, "The Cost of Corrosion and the Need for Research", to U.S. DOE, Office of Energy Systems Research (November, 1983). 
- Electric Production Systems (non-utility)

- Primary Metals Industry

- Industrial Chemicals and Gases

The following is a summary of the background, key corrosion problems, potential impact, and research activities in each area as presented by the invited speakers.

\author{
Corrosion of Buildings and Structures \\ Professor Carl E. Locke \\ University of Oklahoma \\ Norman, Oklahoma
}

\title{
Background
}

The recent publicity from the deterioration of the Statue of Liberty and the collapse of an interstate highway bridge in Connecticut has generated much interested about corrosion problems in concrete and steel. The problem is especially serious with bridges where deterioration can cause hazardous conditions resulting in loss of life. However, detericiration of parking garages, piers, buildings, and roads also have a significant impact on the economy and safety.

\section{Potential Impact}

A GAO report issued in 1979 estinated that it would cost betweer $\$ 4$ to 5 billion to restore corroded bridge decks in the United States. This is mainly the result of spreading 10 to 12 million tons of deicinc salts per year on them and the roads.

Additional econonic benefits would result from avoiding replaceinent of piers, buildings, roads, and parking garages. Societal benefits also would accrue, such as preventing loss of life and maintaining the aesthetic qualities of historic structures such as buildirgs, monuments, or statues. 
Key Corrosion Problems

The key corrosion problems with concrete and steels are well defined, and much is known about the mechanisms of degradation, factors influencing corrosion rates, and methods of control. However, there is a need to continue the study of corrosion control methods for prestressing tendons (rods) in both pre- and post-tension systems.

The problems stem from the fact that concrete is a porous, high resistivity medium that allows for entry of chloride or other ions from road salts or airborne particulates, which can destroy passivity. Corrosion problems tend to be localized in nature on a macroscopic scale, such as the spalling of concrete due to reinforcing bar corrosion and build up of products, or general such as the breakdown of protective films on "weathering" steels.

\section{Research Needs}

Much fundamental and applied research is necessary to better characterize, analyze, and control these corrosion problems. Fundamental research to identify chloride level and type, oxygen level, influence of cement types, and protective system problems are a high priority for better control of the corrosion in reinforced concrete structures.

Applied research should focus on cathodic protection needs such as development of reference electrodes, anode systems, and protection criteria. Investigation of coated rebars should include research on the effectiveness of galvanizing and other metal coatings, and the role of metallurgy/composition of the substrate steel on the coating. The use of different coatings for different layers in multilayered reinforcements can also cause problems. More specifically, the use of epoxy coated rebars in only a portion of the mat can cause serious problems. In many states the top mat of reinforcing steel is coated and the bottom mat is uncoated. This can lead to a combination of a very smal 1 anode in the coated mat and a very large cathode (the uncoated mat). Severe localized corrosion results. Research on site 
measurements of corrosion rates, and corrosion rates in prestructural systems also needs to be conducted.

Finally, measures for controlling corrosion need to be studied. Overall design studies, including concrete quality and options for cover, should be investigated. Methods to seal concrete--such as overlays or membranes and silicone-based sealants--need further research because data obtained to date have been inconclusive. 0evelopment of better inhibitors and some non-salt deicers are also important to the prevention of corrosion in concrete and steel.

\section{Corrosion Problems in Transportation Systems \\ Dr. Dexter Snyder \\ General Motors Corporation \\ Warren, Michigan}

\section{Backgriound}

The transportation sector, and more specificaliy the automotive industry, faces increasingly greater impacts due to corrosion. Before 1950 there was virtually no catastrophic corrosion for automobiles in the United States. The initial signs of body corrosion appeared in 1955 and accelerated through 1970 where body perforations became prevalent in some geographic regions. It is no coincidence that road salt usage in the United States increased tenfold during the same period between 1950 and 1970 .

Corrosion costs in the automotive industry influence the overall costs of transportation. Increased capital costs result in the need for excess capacity and the requirement for redundant equipment. Control costs result in increased maintenance and repair as well as corrosion prevention costs. Design costs are increased as new materials of construction, corrosion allowance, and special processing techniques need to be incorporated into the production process. Other associated costs are for loss of product, technical support, insurance, and increased parts and equipment inventory. 
Potential Impact

The cost of corrosion in the United States has been estimated at $\$ 122$ billion (1982). It is postulated that almost $\$ 17$ billion of this amount could be saved using presently available corrosion prevention techniques. The predominant share of this avoidable cost can be saved in the area of personally owned automobiles where estimates of avoidable corrosion costs are $\$ 10.5$ billion, or about 62 percent of the estimate for the entire United States economy. Thus, corrosion control in the automotive industry can have the most dramatic economic impact.

Key Corrosion Problems

The corrosion problems in the automotive industry are diverse and encompass many different types of corrosion. Corrosion problems in the automobile are significant not only in the outer body, but also in the mechanical support, fuel delivery, and electronic systems. Problems due to pitting corrosion, crevice corrosion, galvanic corrosion, stress corrosion cracking, intergranular corrosion, exfoliation, dealloying, fretting, and corrosion fatigue are worthy of investigation.

Design and corrosion prevention techniques have emerged as the major steps taken to combat the overall corrosion problem. Design considerations in the automobile joints, closed sections, entrapment areas, decorative trim, part configuration, electrical, and liquid passages and reservoirs are concerned with corrosion avoidance. Methods of corrosion prevention employed to mitigate problems include electroplated coatings, electrophoretic coatings, ion implantation, laser surface alloying, hotdipped coatings, clad coatings, sprayed metal coatings, vapor-deposited coatings, conversion coatings, organic coatings, petroleum-base rust preventatives, and sealers.

Another key area is the need to measure and test for corrosion damage. Corrosion measurement techniques range from the simple, such as appearance and weight change, to the sophisticated, including mechanical and electrochemical techniques. Corrosion testing includes both field 
testing (atmospheric corrosion, fleet investigation) and laboratory testing (electrochemical techniques, imnersion techniques, simulated service, proving ground tests).

Research Needs

Improved coatings and corrosion-resistant metals are the two areas which are currently receiving the most research attention in private industry. Different coating types such as electroplated coatings, conversion coatings, organic coatings, and other nonconventional coatings have shown potential for corrosion control. The most important needs are:

- Precise corrosion prediction models to be used in conjunction with CAD/CAM at the design stage

- Improved field data collection to support R\&D and models

- Meaningful short-tern corrosion tests (accelerated tests)

- Improved barrier coatings

- Optimal sacrificial coatings

- Protection for electronics

- Protection when alternate fuels such as methanol are used

- Continuing education for designers

- Less corrosive road deicer salts.

Longer term research needs to address better tests, improved corrosion prediction, and improved data collection.

\section{Corrosion Problems in the Electric Power Industry}

Dr. Adrian Roberts

Electric Power Research Institute

Palo Alto, California

Background

Materials degradation in service represents one of the major technological factors that limits the efficiency and viability of the electric power industry. In an industry where the reliability of 
delivering power is of the utmost concern, it is extremely important to use the best available corrosion control and prevention measures. At the present time three approaches are being used. The first controls stress through improving design features. The second is to use more "forgiving" or less susceptible materials of construction. The third is to modify the environments to make them less aggressive to the materials. The principal research thrusts, in both the nuclear and fossil fuel powered generating plants, are to determine the role of environmental effects, and to identify wear-out mechanisms that would prevent a 30 year (or longer) life being attained.

\section{Potential Impact}

The incentive for the improvement of corrosion control in electric power plants is clear cut. Currently, forced outages require utilities to invest capital in costly and fuel-intensive back-up generation equipment in order to maintain system reliability. Improved corrosion control or prevention for power systems will result in restricted use of fossil fuels and in increased capacity factors with resulting improved economics for all power plants. For example, at the present time some 7 to 8 percent of installed capacity is unavailable due to forced outages caused by materials problems. Although failures of key components do not occur often, when they do outages may last for months, and the replacement power cost is large.

\section{Key Corrosion Problems}

Both nuclear and fossil fuel powered generation plants experience significant corrosion problems which cause forced outages. It is forced outages, not initial cost, which is the key factor in overall plant economics. Therefore, materials must be reliable with cost becoming a less important factor. Severe problems can occur in the heat exchangers where stress-corrosion cracking, general corrosion, and erosion are observed to cause cracks and faitures in steam generators and condensors. Embrittlement, corrosion fatigue, and stress-corrosion 
cracking are also significant problems for turbines. These problems have lead to rotor bursts, disc cracking, and blade cracking resulting in catastrophic failures.

Nuclear power plants experience unique corrosion problems due to materials applications in a more hostile environment. Additionally, corrosion problems must be a major concern because of the severe consequences of a catastrophic failure. Comon corrosion problems in nuclear plants include stress-corrosion cracking and creep/corrosion in the fuel rods, control rods, and fuel assembly channels in the reactor core. Corrosion problems are also significant in the pressure boundary vessel where radiation embrittlement, corrosion fatigue, and intergranular stress-corrosion cracking are often observed in the vessel and associ ated piping.

Research Needs

The trend is to use more expensive but more reliable materials that are resistant to corrosion problems. Examples of materials under invesligation to combat known corrosion problems are:

- Titaniurn alloy blades for turbines

- Titanium (or stainless steel) tubes for heat exchangers/condensors

- Ferritic stainless steel support plates or thermally treated Incone $\left.{ }^{(}\right)$(a) Alloy 600 tubes for heat exchanger/ steam generator

- "Clean" low alloy steels for pressure vessels and Type 316 NG and/or carbon steel for piping

- "Barrier" cladding on the i.d. and Beta-quench Zircaloy" on the o.d. for nuclear fuel rods

Other approaches have been well documented in recent Electric Power Reseal ${ }^{\wedge} \mathrm{ch}$ Institute reports.

Ta) trademark of Nickel Company of New York. 
Corrosion in Non-Utility Electricity Production Systems

Dr. Frank McLarnon

Lawrence Berkeley Laboratory

Berkeley, California

Background

Non-utility electricity production systems include several technologies, but principally primary and secondary batteries, fuel cells, photovoltaic devices, and thermal electric systems. Corrosion is a key problem in all of these for several reasons. First, high performance goals of energy, power, and efficiency require aggressive conditions conducive to corrosion. These severe conditions usually include highly oxidizing or reducing conditions, high temperature, or large chemical or thermal gradients or combinations of these.

The future of these technologies, whether they ever achieve significant market penetration, is critically dependent on life-cycle costs. Reducing life-cycle costs is dependent on stable components made of inexpensive, abundant materials which are corrosion resistant. The trade-offs which will have to be made between corrosion resistance, desirable mechanical properties, and costs of candidate materials will determine the future of these technologies. Thus, the ability to solve corrosion problems could be the determining factor in the ultimate commercialization of these systems.

\section{Potential Impact}

The potential for batteries, fuel cells, and photovoltaic devices is enormous if the problems of cost, efficiency, and specific energy can be solved. The use of these alternative generation technologies can significantly reduce dependence on foreign oil by reducing the amount of (fossil-fuel based) peaking energy required on electric utility systems; by providing technologies other than the internal combustion engine to be used for transportation; and by enabling the use the sun's energy for direct conversion into electricity. 
Key Corrosion Problems

The corrosion problems which are prevalent vary according to the individual technologies. In ambient-temperature, secondary batteries the major corrosion problems include anodic oxidation of positive-electrode current collector/substrate materials, corrosion of negative electrodes (aluminum, lithium, zinc), chemical attack of separator materials, and chemical attack of all container materials (e.g., plastic materials in zinc/halogen cells).

The corrosion problems for high-temperature, secondary batteries are more severe due to the more stringent conditions. Major problems are the corrosion of positive-electrode current collector materials by sulfur and sulfides, corrosion of cell container materials by sulfur and sulfides, and chemical attack of insulators and separators.

Fuel cells have unique corrosion problems due to their cataly:t requirements and hydrogen environment. Important fuel cell corrosion problems are the anodic oxidation of air electrode catalystsuppor: materials, corrosion of electrocatalysts at open circuit, and chemical attack of cell seals and electrode materials (e.g., sulfidation of nicsel oxide in molten-carbonate fuel cells).

Photovoltaic devices offer their own unique corrosion problems due to the combined thermal and electrochemical environment and materials of construction used. Key corrosion problems for photovoltaics are galvanic corrosion due to dissimilar metals in metallic components, galvanic corrosion due to potential differences between solar cell and grounded supporting frame, anodic dissolution of n-type photoelectrodes, and chemical attack of cell components.

\section{Research Needs}

Important corrosion problems need to be solved before any of these systems reach commercialization. Fundamental data and theory are currertly missing which will guide materials selection for each of these systemis. Materials selection includes current collectors, electrodes, catalysts, and container materials for ambient-temperature and 
high-temperature batteries and fuel cells. Photovoltaics have different materials selection problems. There is a need to identify new metallic components, identify new photoelectrode materials, and improve materials for liquid junction devices.

\author{
Corrosion in the Primary Metals Industry \\ Dr. Rudolf Keller \\ EMEC Consultants \\ Export, Pennsylvania
}

Background

The electrowinning and electrorefining industries are energy and materials intensive with large potential for energy and materials conservation. These industries include the production of primary metals such as aluminum, magnesium, titanium, sodium, copper, zinc, lead, chromium, and manganese and the refining (purification) of copper and aluminum. Traditionally, corrosion problems were not solved but processes were modified, and cell designs altered to circumvent corrosion. As a consequence, these traditional processes, in particular the Hall-Heroult process to produce primary aluminum, often are operated with low energy efficiency, even though some design modifications have been incorporated over the years. It is improved material stability, achieved either by corrosion prevention or by the selection of new materials that could lead to new process alternatives and modifications with greatly lowered energy consumption.

\title{
Potential Impact
}

An extensive corrosion effort would be expected to impact materials development for new processes and could include studies focussing on specific problems, as summarized below. As a consequence energy conservation in this industrial sector could be expected. Increased energy efficiency would place the depressed metals industry in a more competitive position, and make it better able to respond to the 
anticipated recovery, particularly for zinc and aluminum. As raw material sources are relatively plentiful for aluminum it will be especially important in the future to have more energy efficient processes to produce the metal. The goal for 1985 is a 20 percent reduction in energy usage.

The main benefit from an extensive corrosion program would probably not result in direct material conservation. Rather, use of improved materials would result in new process alternatives with reduced energy consumption. There are many opportunities to help improve overall process efficiency by introducing new and improved materials for anodes, cathodes, and cell structures.

\section{Key Corrosion Problems}

Electrorefining processes can be viewed as fast, controlled corrosion processes, and their development should benefit from a better unders anding of general corrosion mechanisms.

Electrowinning offers several possibilities for materials conseryation, such as improving separators in titanium electrolysis, or solvini corrosion problems in the electrolysis of metal chlorides. Sone key problem areas are the need for better, corrosion resistant sensors to imp ove process control; more stable anodes and cathode materials; and corrosion on open circuit during shut down of the newer bipolar celis.

Aluminum electrolys is is the largest metal winning industry and of ers insight into typical materials stability problems. A deep metal jool with an unstable surface is being used to avoid aluminum carbide formation and its subsequent dissolution in the electrolyte. A large mode to cathode distance has to be maintained, resulting in high onmic losses. There is a need to develop a stable anode so that consumable carbon anodes can be eliminated. Present sidewall materials need $\mathrm{t}$ s be protected by a ledge of solidified electrolyte, which puts restristions on the heat balance of the cell. In aluminum chloride electrulysis cells improved materials are needed for handling chlorine and chiorides. 
Research Needs

The greatest benefits can be derived from the development of novel, more stable anode, cathode, sidewall and sensor materials. Often new approaches are necessary for the study and testing of such materials for high temperature electrolysis.

\author{
Corrosion in Industrial Chemical and Gases Industry \\ Or. Larry Gestaut \\ Eltech Systems Corporation \\ Fairport Harbor, Ohio
}

Background

This industrial sector is primarily concerned with the chloralkali industry, wherein chlorine, hydrogen, caustic soda, caustic potash, soda ash and sodium chlorate are produced. In the basic chloralkali process salt or brine is electrolyzed to produce chlorine and hydrogen gases, and hydroxyl ions. Three types of cells are in use: the mercury, diaphragm and membrane cell, and each type produces the above chemicals in different ratios or forms, particularly the caustic. Handling caustic and chlorine solutions and wet and dry chlorine gas, as wel? as hydrogen, poses some severe corrosion problems. Corrosion in turn causes product contamination as well as eventual component failure.

Over 20 companies in the U.S. had the capacity to produce some 40,000 tons/day of chlorine and 41,500 tons/day of caustic soda in 1983 . The largest producers were Dow Chemical, PPG Industries, Diamond Shamrock, Hooker Chemical and 07 in Chemical. Production in 1983 was about 10 percent greater than in 1982. Capacity utilization was greater in 1984 than in 1983, but in 1985 the production capacity will fall about 4 percent below the 1983 level. 
Potential Impact

Chlor-alkali plants find it difficult to be profitable unless they use low cost hydroelectric power or cogeneration. Thus, the incentive for investing in R\&D to improve processes, or materials to alleviate corrosion problems is often limited. Emphasis is often on reducing energy consumption. In the U.S. the annual growth rate for chlorine consumption is estimated to be about 3 percent; and that for caustic soda consumption to be about 3 percent, also, for the next 10 years. With prices for chiorine and caustic at a relatively low level it may be appropriate for government or academia to undertake some of the corrosion related research.

Key Corrosion Problems

In mercury amalgam cells steel is used, but gradual corrosion can result in the build-up of hydrogen in the cells.

In diaphragm cells, hydraulic pressures force hypochlorite ions into the product caustic stream, resulting in the formation of chlorate ion. The impure caustic is removed from the cell and evaporated to increase concentration. Evaporators are the single most costly item in diaphragm cel1, chlor-alkali plants, costing as much as $\$ 80$ million. As the heated caustic becomes more concentrated and more nearly anhydrous, corrosion, even of nickel, becomes severe. Complete solutions to this problem have not been found to date.

In membrane cells, total alkaline earth metal concentration in the urine must be kept below 50 ppb for satisfactory membrane life. Heavy matals can also cause problems with membrane operation. Titanium parts in membrane cells are also subject to crevice corrosion, particularly in the presence of gasket materials. On the cathode, a low overpotantial coating such as rough nickel is used to reduce cell voltage. Unfortunately, the coatings can deteriorate, resulting in performance loss and product contaraination. I ron in the brine feedstock can depsit on dimensionaliy stable anodes or, in diaphragm cells, as 
metal on some cathode structures. Such deposits can adversely affect cel1 voitage.

In chlorate producing cells the titanium or steel cathodes are not stable when power is not applied or interrupted. This is a serious ongoing corrosion problem and needs to be addressed.

\section{$\underline{\text { Research Needs }}$}

Improved materials and fabrication methods are needed for the evaporators and concentrators in the chlor-alkali plant. Preferably these materials should be similar in cost to existing materials being used, or show a marked improvement in life cycle costs or other factors such as safety and maintenance costs. Stable cathode materials are needed to replace steel and titanium in chlorate cells. Better low cost catalytic surfaces are needed for diaphragm cells so that they do not corrode and contaminate process streams, causing corrosion elsewhere. Titanium alloys more resistant to crevice corrosion need to be developed for anodes in diaphragm cells.

Thus, there are several areas where materials improvements would help control corrosion problems and help improve the overall economics of the processes. As old plants are retired and new plants installed, there will be an opportunity to take advantage of research findings with respect to corrosion controt and prevention. 


\section{TECHNICAL DISCUSSION GROUSP FINDINGS}

As mentioned earlier, to facilitate the collection, collation and screening of ideas for research to conserve energy and materials in the various sectors of interest, the participants were divided into four groups. The purpose of these groups was to provide a technical focus to the discussions. The four groups were arbitrarily called:

- General Corrosion

- Localized Corrosion

- High Teriperature Corrosion

- Corrosion Control and Prevention.

Each liscussion Group Leader had some flexibility in the conduct of the group discussions. It was not until later that similar criteria were applied to screening the research needs and prioritization was accompl ished.

In the following paragraphs an overview of the findings of each discussion group is presented. There is some overiap, which was expected, because of the arbitrary nature of the division into groups. For example, under the general, localized and high temperature corrosion categories, it was only natural to discuss some preventative methods. Some topics falling under localized corrosion were also brought up in the general corrosion sessions. Nevertheless, the general guidelines provided to the discussion group leaders were that (1) general corrosion was concerned with uniform attack at near ambient temperatures in common environments, where failure rates were such that time to failure could be predicted. Conversely, (2) localized corrosion normally resulted in catastrophic failures due to perforation, cracking or erosion, for example. Still, the processes occurred at near ambient temperatures in fairly common environments, although it was not easy to predict when failure would occur. In (3), high temperature corrosion, attack occurs at elevated temperatures, usually in gaseous or liquid environments specitic to particular processes or devices. Corrosion can be slow, as in oxidation, or rapid as in liquid metal attack. Corrosion control and prevention (4) was to include physical, mechanical, chemical and electrochemical methods for conserving materials and preventing failures, thus conserving energy. 
General Corrosion

The discussions centered on five major topics, namely:

(1) buildings, including bridges, roads, garages and pipelines;

(2) transportation, including automobiles, railways, ships, aerospace, subways and people movers; (3) energy generation and storage, including batteries, rotating equipment, nuclear power and transmission;

(4) petroleum industry; and (5) other industries.

Buildings and Structures

Several direct and indirect corrosion related problems and research needs were identified. With respect to buildings, the problem of corrosion of metallic panels used as facing due to condensation in the wall cavities was identified. The extert of the corrosive nature of "acid rain" is not known, but the need for the restoration of public buildings and monuments is well known. There is a need for establishing a data base on the relative effects of the environment:
- pollution
- soils
- humidity
- acid rain
- carbon dioxide
- sunlight
- oxygen

and their interaction so that existing knowledge can be used in practice to control or prevent corrosion. As a corollary, there is also a need for establishing building codes and specifications that provide a tradeof $f$ between the costs and the benefits of corrosion prevention and control. If "expert" systems could be estabilished these could prove to be useful, especially in the design stage, for preventative measures. For existing buildings and structures, such expert systems perhaps could help select control methods to limit degradation. The expert systems could have the capability of providing models for corrosion attack in some well understood systems.

The corrosion of steel in concrete was recognized as a inajor problem in buildings, bridges, parking garages, and other structures. Moisture and chloride ions from road salt or components of the concrete 
mix itself cause corrosion of the reinforcing steel in the concrete. Both prestressed and conventional reinforced steel structures are susceptible to this type of damage. The resulting corrosion products are voluminous and impart a stress to the concrete, which in turn cracks and exfoliates. Corrosion occurring on the surface of the high strength prestressing tendons can be accompanied by hydrogen evolution. This corrosion generated hydrogen can lead to hydrogen embrittlement of the steel. Various coatings are used on the steel, but there is a need to establish the effectiveness of some of these coatings. For example, epoxy coatings, if improperly coated, or damaged in transit, storage or installation can permit corrosion to occur at the holidays. Another unknow 7 is the long term effect of cathodic protection in changing the local shemistry at the steel-concrete interface, and its effect on corrosion.

Problems with other structures include the general corrosion of ste 1 , both structural members and cables, particularly in bridges. Such steel can be exposed to a wide range of environments, from marine to "ndistrial. New "weathering" steels have provided some relief, but the failure of these and other new construction materials should be documeated now before they are put into wider use. Thus, property data, corrosion rates, and non-destructive testing methods and instrumentation are needed. Part of the problem with weathering steels is that they were designed for alternate wet and dry conditions. In the northeast United Stated many transmission poles and towers were built from such steel, but they are performing poorly under conditions of being wetted for extended time periods. The problem is most acute where crevices exist, and can lead to bolt failure, for example. Research is needed on how best to renove corrosion products, and prepare the surfaces for coatinis so that crevices are covered.

Underground corrosion was another topic considered to be important. Systems affected included pipelines (gas, water); grounding rods and systems; pilings and supports; survey markers; $0 i 1$, gas and geothermal wells. Not only are the conditions of the soil and other materials in contact with the above important, but the role of stray ac (from distribution systems) and stray dc (from cathodic protection 
systems) is not always appreciated. Stray currents can cause severe, general corrosion problems. White the use of plastic pipe is increasing, the long term behavior of these materials is yet to be well documented.

\section{Transportation}

The most visible, and most documented corrosion problems in the transportation sector are found with automobiles. However, many of the problems are more localized than general in nature. Nevertheless, considerable attention has been given to developing coatings for corrosion prevention. These include galvanized (hot dipped or electrolytically applied) steels, organic and inorganic coatings (special waxes, zinc-rich paints) and also substituting materials and incorporating inhibitors to fluid containing systems, such as for cooling and lubrication. For example, aluminum alloy radiators save weight and contribute to reducing fuel usage but when connected to the engine block, usually a ferrous material, galvanic corrosion can occur. Another specific corrosion problem with automobiles is related to corrosion of electrical contacts, especially battery teminals.

Again, discussion centered on the present need for valid corrosion tests (tests which can be correlated directly with behavior in use); an accessible data base and corrosion nodels where appropriate; and a better understanding of life-cycle costs for various corrosion protection schemes, particularly for military and other government vehicles. In the future, as the use of substitute fuels for gasoline becomes more prevalent, the problem of the corrosive nature of methanol will have to be addressed, if this is used in automobiles.

With subways, the need for better coatings was discussed. Corrosion of car-to-car contacts was also identified, as was the problem of the electrical conductors providing a source for stray current corrosion. Fretting corrosion was considered a major problem with railroads, as was the need to provide protection to tank cars containing hazardous materials, such as acids, explosives, fertilizers, chemicals, or reactive gases. Better coatings are needed to prevent general 
corrosion of the rolling stock, while ways must be found to prevent electrically induced failures of the tracks (rails).

In the aerospace sector, the need for detectors to provide an early warning of corrosion in critical systems was identified. Also, the behavior of the new composite structural materials, and new lightweight alloys (e.g., lithium/aluminum) has to be investigated and documented for a variety of environments ranging from high altitude to saltspray in aircraft carriers. Volcanic ash carried in the atmosphere now seems more prevalent, and this might provide a scouring action for coatings and giasses. Another problem specific to aircraft is the corrosion problem associated with bacterial growths in fuel cells (tanks).

The need for better knowledge and documentation, and standardization for cathodic protection of ships and floating structures was another topic of discussion, especially as new materials, such as aluminum alloys, are being used. The protection of structures in deep water is ancther problem because of differential aeration effects. Little or no oxygen exists as greater depths are reached. Also, work has only just begun on the protection of submerged pipelines between rigs and shore. More needs to be known about the effectiveness of cathodic protection here also, and models should be developed for the systems. A problem, which has received less publicity, is the corrosion of the inside structures of ships, particularly those carrying cargo. No data exist on the corrosion of high strength, low alloy steels being used to fabricate nilitary ships.

Energ: Generation, Distribution and Storage

In the nuclear generation sector the choice of methods and materials for long term storage (up to 1000 years) is still being debated. Corrosion attack will play an important part in any decision made. More sophisticated models are needed to predict materials degradation over such long time periods. Present models are too simplistic. A)so, the synergistic effects, if any, of radiation on corrosion processes need to be established. In the near term, there is a problem of selecting materials for containers to hoid nuclear waste materials, 
particularly liquids. Corrosion data are needed so proper choices can be made.

With conventional electricity generating stations a number of problems were identified. For example, in the cooling towers the best, low cost corrosion inhibitors are chromates. However, these have been banned for ecological reasons. Now there is a need for a non-toxic, effective inhibitor. For structures, whether in the station or in distribution systems, there are problems with stray current corrosion, especially of grounding systems. Reasons for corrosion have to be determined, and it would be helpful to have a model for predicting time to failure so that maintenance can be scheduled efficiently. The same is true for transmission tower corrosion, which is strongly dependent on environmental factors.

Many problems are still to be found in the petroleum industry; however, some involve localized corrosion failures such as stresscorrosion cracking. General corrosion attack is caused by salt water contaminating gas and crude oil. In the presence of hydrogen sulfide and carbon dioxide sulfuric acid may form and corrode the pipes. Similar problems are found with enhanced oil recovery schemes. Downhole monitoring devices could serve a useful purpose by providing data on temperature, rock strata, chemical species present, and so on.

Key corrosion problems identified with geothermal power systems were rapid attack caused by the high salinity brines encountered at well-heads. Conversely, with low salinity brines, if they contain high concentrations of carbon dioxide, ferrous materials are readily corroded. Cooling systems components are corroded when the coolants contain sulfur-bearing impurities. The impact of these problems is higher system costs in terms of materials of construction and controls.

Materials problems in batteries and fuel cells have received Inuch pubiicity. Examples discussed were the corrosion of the positive grids in lead-acid batteries, which limits useful life; the corrosion of current collectors and electrode supports in lithium-nonaqueous electrolyte cells as well as lithium-molten salt electrolyte cells; and the degradation of carbon electrodes by air (oxygen) or chlorine. Lithium metal, or alloys, used as anodes are attacked by traces of water in non- 
aqueous systems, and by-product hydrogen is produced. Calcium has a similar problem. While being attractive as a lightweight, high energy anode material it does not readily form passivating films to control the rate of the desirable energy producing reaction. Ceramic materials in batteries and fuel cells also are subject to degradation, whether used as solid electrolytes, electrolyte supports, insulators or seals. In sodium-sulfur batteries, for example, the life limiting components are the beta-alumina electrolyte and the alpha-alumina seals. Performance is limited by the degradation of the electrolyte. In high performance, high reliability batteries of ten failure mechanisms are associated with degradation of glass-to-metal and ceramic-to-metal seals.

Other industries

In the pulp and paper industry corrosion is a major problem and has been estimated to cost about $\$ 350$ million annually. Corrosion occurs in boilers and driers, and is usually associated with wet processes. Sulfur dioxide being present in some operations causes a problem. The same is true of ore roasters in minerals processing. Corrosion attack is severe in desalination plants, particularly the evaporators, and there is a problem with handling and storing the concentrated brines. In the agricultural industry, corrosion problems arise with the handing and storage of fertilizers, thus better materials are needed. Irrigation coupled with use of fertilizers increases the salinity of ground water, and can increase corrosion of pipelines and cables. the extent of this problem is not known and needs to be Jocumented. General corrosion of farm equipinent, buildings and structures is well known, and improved materials or coatings would alleviate this problem.

\section{Localized Corrosion}

These discussions focussed on a variety of corrosion phenomena that could lead to localized attack, hence catastrophic failure. Included were (1) stress-corrosion cracking, hydrogen stress cracking, 
(2) pitting, (3) crevice corrosion, (4) filiforr corrosion,

(5) intergranular attack, weld decay, (6) corrosion fatigue,

(7) erosion-corrosion, and (8) cavitation corrosion. To a lesser extent localized corrosion resulting from coating defects also was discussed.

The above listing does not represent an indication of the relative severity of these forms of corrosion, nor an indication of the relative impact on materials and energy conservation. The same is true for the topics described for the other technical discussion groups.

\section{Stress-Corrosion Cracking}

In the paper industry there are several problem areas. For example, in continuous digesters cracking was associated with a circumferential weld. The solution was to grind out the cracks, reweld, then stress-relieve by heat treatment. Such a procedure led to long down time, and loss of capacity. Recently, anodic protection has been studied as a preventative measure, but the problem here is the need for a suitable reference electrode to operate under the conditions found in the digester. In deaerators, where essentialiy pure water is being handled, there is a problem with stress-corrosion cracking. The discussions revealed that there is also a problem with sensitized Type 304 stainless steel in high purity water in boiling water reactors.

other related problems in the nuclear industry relate to cracking associated with "denting" in heat exchangers. Cracking occurs near the bends when Alloy 600 or Inconel $^{\circledR}$ are used for the primary water tubes. Alloy 600 also is subject to alkali cracking in pressurized water/steam generators, again close to the tube sheet crevices. Problems with high strength steels and stainless steels were also discussed, particularly with respect to chloride initiated cracking. Solutions to the problems have been investigated, and these include materials substitution and the use of weld overlays. With titaniun alloys the cracks propagate very quickly and failure can be very rapid. Some work is under way to model the cracking phenomenon, but there is a need for continuing studies. 
In fact, the topic of developing a better understanding of stress-corrosion, hydrogen and sulfide cracking frequently arose in the discussions, along with the need to formulate theories and models, and obtain the data necessary for their evaluation.

Stress-corrosion cracking and related corrosion failures are pervasive throughout industry and constitute a problem in deep well drilling; pipelines, particulariy under coatings with holidays and disbonds; aluminum alloys used for aircraft landing gear; and chemical process equipment. There is a need to study the mechanisms, understand what criteria are important and then take preventative measures. Currently, approaches include heat treating structures to relieve stresses, using inhibitors, or turning to more resistant, hence more expensive alloys.

\section{Pittirg Attack}

The discussions revealed that pitting corrosion is widespread throughout industry in the sectors of interest, and is to be found associated with a wide range of materials.

In the chlor-alkali industry, the presence of chloride ions (halocien ions are usually responsible for the breakdown of protective films and subsequent pitting attack) causes severe problems with anode cans and with evaporators. With the latter the rate of attack can be as high as 250 mils per year*. As the cost of evaporators can comprise a third of the total plant cost the problem is severe one. The present approach is to substitute Nickel 201 alloy for Nickel 200, because the low carbon content results in a lower susceptibility. While the cost differential is 10 to 20 percent, Nickel 201 is used because no other acceplable material presently exists. With new capacity a low cost, more resistant material would be welcomed. However, as with many mature industries, the cost of more expensive materials of construction, dimensionally stable anodes (DSA), excess capacity, etc., is factored into operating costs and passed on to the consumer. At present, DSA's have a finite life due to degradation of the electrocatalyst coating, but this

* $1 \mathrm{mil}=0.001$ inch $=25.4 \mu \mathrm{m}$. 
is not considered a service failure but a maintenance problem. Improved coatings would conserve materials and energy by reducing the frequency of DSA replacement.

In the general chemical industries and electric power generation, pitting corrosion of heat exchangers is a problem, particularly when sea or brackish water is used as the coolant. Fouling by bioorganisms (bacteria, plants, animals) can contribute to the problem, but often the result can be classified as a type of crevice corrosion. Fouling in itself is harmful because it reduces heat transfer to the meta? surface and restricts and/or impedes the flow of coolant. Consequently, more energy is required to circulate a given volume of coolant, and the heat exchanger has to be over-designed to allow for the fouling that will occur. One approach to solving the fouling problem has been to use coated titanium and pass an electric current to provide a local environment not suited to the accumulation of organisms.

Anodic protection also has been tried to control pitting corrosion, but there is a need to document the findings to determine the relative effectiveness of anodic or cathodic protection systems. In automobile cooling systems inhibitors have been used to prevent localized attack set up by galvanic action when aluminum radiators are used in conjunction with ferrous engine blocks. In the building industry, sacrificial coatings are used to protect aluminum alloy siding and roofing. Alclad composites are used, but at an extra cost. More resistant aluminum alloys, especially for use near cherical plants or the ocean, would conserve material, and indirectly, energy.

The mechanism of pitting of aluminum is not well understood, nor the phenomenon of tunnel corrosion, used to texture aluminum capacitor foils. Discussions revealed that better experimental techniques are needed to investigate the problem. A data base needs to be established, but the data first have to be critically reviewed. Finally, there has to be a transfer or distribution of the information in this data base to the plant designers, engineers, and others with a need to know. 


\section{Crevice Corrosion}

Here again, part of the discussion revolved around obtaining a better understanding of the mechanisms involved, the materials susceptible, developing better methods of investigation and experimental probes, and studying the role of passivation, depassivation and repassivation. There is a lack of quantitative data to support the models, such as rate of acidification in the crevice; the behavior of ions in concentrated solutions, and hydrolysis inside the crevices; identifying the reaction species in situ in real time, and so on. This type of work was considered to be too mundane to be conducted at universities or colleges.

Some specific examples were identified. For example, the addition of copper to stainless steels is good in theory, but in practice does not prevent crevice corrosion in sea water. The addition of less than 1 percent palladium to titanium prevents corrosion in chioralkali applications, but the protective mechanism is not understood, and the raterials are nearly double the cost of straight titanium. Research is needed to investigate the use of lower cost coatings, or surface modification or alloying by ion implantation. In nuclear waste containment, titanium has to be used because of the long, reliable life needed. A suitable lower cost material would free this metal for other applications. In the automotive industry traditionally there has been a problem with crevice corrosion (and "poultice" corrosion). Design changes have circumvented much of the problem, but in testing regines there is not a good correlation between alternate immersion tests and practice because the total extent of damage is greater than the sum of the periods of wetting. It is difficult to predict when crevice corrosion will occur. Part of the problem is that mechanical forces are generated by the expansion of the corrosion products and/or the poultices of mud, road dirt, whatever.

\section{Filiform Corrosion}

This is not a very common form of corrosion, and when it does

occur the results are more cosmetic than detrimental. Nevertheless, the 
topic was raised in the discussions because filiform corrosion has been found associated with photovoltaic devices, between the silicon and gold contacts. This causes higher electrical contact resistance, hence a loss of electrical output and lower efficiency. The problem is currently being investigated.

\section{Intergranular Corrosion}

The discussion included a number of types of corrosion under this heading, including weld decay and knife-line attack and exfoliation. It was obvious that much work had been done with steels in many environments, and the problem with these materials is well understood. Work is underway looking at inconel ${ }^{\oplus}$ in nuclear applications, and the problem here should be under control in a couple of years. However, other metals and alloys are susceptible, and have received less study. Examples are titanium and aluminum. In addition, the role of trace elements and minor impurities in metals and alloys is not well understood.

Another area for consideration, and perhaps research, is whether there are transitions between intergranular corrosion and stress-corrosion cracking on one hand, and corrosion fatigue on the other. In other words, can a global picture of corrosion and its interaction with nechanical forces be developed? One example quoted was the failure of a loose bolt on a side rail of a truck. It was concluded that crevice corrosion occurred first, which led to more extensive intergranular cracking, which in turn contributed to a fatigue failure.

In exfoliation corrosion, intergranular attack is extensive enough to allow grains of the metal to become detached and lost. Resulting weight loss is far in excess of what might be expected from corrosion alone. Susceptible metals include aluminum and titanium. Aluminum alloys used for aircraft skin panels are heat treated to control their temper, hence improve their resistance to attack. However, there is a need to develop a good test method. Aluminum electrodes used in aluminum-air batteries dissolve unevenly (like sacrificial magnesium anodes) and provide less than 100 percent efficiency because of loss of 
material. Better alloys are under development. In perchlorate production cells, titanium has been used to replace mild steel. However, hydrides form and exfoliation occurs, resulting in loss of material. This problem has yet to be solved.

\section{Corrosion Fatigue}

A few specific examples were discussed. In the aircraft industry, aluminum alloys are subject to this type of corrosion. Cracks start at rivets, propagate and lead to failure. To circumvent this the wings are inspected at regular intervals. Any cracks found are drilled out and new oversize rivets installed. When this approach is no longer pract:cal the complete wing panel has to be replaced. Considerable time, materials, expense could be saved if more resistant alloys could be developed. In the SST (supersonic transport) and other high performarice airplanes, it would be desirable to use lightweight, high strength titanium alloys. However, crack propagation rates are so rapid that the remedy described above would not be feasible. Thus, there is a need for high strength, lightweight alloys resistant to corrosion fatigue.

The paper industry encounters problems from time to time. One example is the failure of large, rotating suction rolls containing many drilled holes exposed to 10 to $80 \mathrm{ppm}$ of thiosulfate in "white water", which also contains some chloride ions. Presently the rolls are made from cast 316 Type stainless steel and cost about $\$ 0.5$ million each, and life is measured in months in the worst case. Approaches to solving the problem include changing to a "duplex" stainless steel; using anodic protection; and controlling the whitewater composition. The problem with the second of these approaches is how to place the counter electrode inside this rotating drum. More resistant alloys are needed, plus a study to investigate the role of oxysulfide ions, chloride ions and combinations of these on the corrosion mechanism. If sulfur acts as an "accelerator" to break down passive films maybe inhibitors could be used to tie up the sulfur containing species. 
In the nuclear industry work is being done on establishing a data base for containment materials. Similariy, a data base is being developed for structures and tethers for oil rig platforms at sea. These data bases are being used to assist in alloy development. In a broader context, what is needed is a universal test model for predicting corrosion fatigue failures. At present, existing tests take too long and cannot be accelerated without changing the relative intensities and frequencies of the corrosion and mechanical components. Also, more data are needed on the role of short versus long cracks, smooth versus rough surfaces, nature of surface films, and the metallography of failures.

Erosion-Corrosion and Cavitation

A consensus was that many times erosion-corrosion problems are accepted as inevitable, and compensated for by over-design, hardening surfaces, cladding or coating and regular replacement during maintenance down times. Costs are passed on to the consumer. A more satisfactory solution would be to develop more resistant raterials of construction at acceptable cost. Such a material could be used, for example, in chloralkali cells where dry, liquid chlorine is pumped through mild steel piping. Where there are constrictions erosicn-corrosion occurs, and penetration/failure of the piping can have serious consequences.

The phenomenon of cavitation is not well understood, with much of the investigative work being done by mechanical engineers. Several theories have been presented including large mechanical forces being generated by collapsing bubbles and electrokinetic processes generating large currents locally. The role of surface films is not clearly understood, nor the influence of the metallurgical condition of the substrate. A multidisciplinary approach is needed to address this corrosion mechanism.

\section{High Temperature Corrosion}

Discussions in this group centered on (1) oxidation, (2) su?fidation, (3) carburization, (4) halogenation, (5) mixed oxidants, 
(6) molten salts, (7) liquid metals, (8) hydrogen, (9) erosioncorrosion, (10) creep and fatigue, and (11) fretting phenomena as they pertained to heat engines, chemical processes, fuel cells and batteries, electrometallurgical and other processes.

Heat Engines and Related Systems

There are a number of systems which are intended to convert thermal energy into mechanical or electrical energy. These include:

- Spark-ignition internal combustion engines (ICE)

- Diesel engines

- Gas turbines

- Systems with a secondary working fluid; for example, boilers coupled with steam turbines, or Stirling engines.

- Magnetohydrodynamic (MHD) electricity generators

- Thermoelectric and thermodielectric generators

- Thermoelectrochemical generators

- Rocket engines.

In most of these systems, high efficiency implies a high maximum temperature. The maximum allowable temperature will be defined by two factors: (a) mechanical criteria for the structural materials, particu1 arly rupture life, and (b) chemical degradation or corrosion. This last factor is principally due to reaction with the high-temperature environment.

The basic limit in most cases is simple oxidation, since other contributions usually make things worse. In general, the temperature limits set by the oxidation rate of the alloy and the acceptable section loss are well-known, and become a design criteria for the system. The theory of oxidation is understood well enough that further research is not justified. However, improved alloys and coatings are constantly being developed by the alloy vendors and the equipment manufacturers. Thus, the only need at this time is the study of adhesion of the protective oxide to the substrate during thermal cycling.

Alloys to be used to moderate temperature ( $<900 \mathrm{C})$ usually rely on the presence of chromium, in amounts greater than 12 percent, to 
provide corrosion resistance. At higher temperatures, $\mathrm{Al}_{2} \mathrm{O}_{3}$ is the preferred protective oxide. Two alloy development problems were identified: (a) how to get enough aluminum into a steel to form a protective $\mathrm{A}_{2} \mathrm{O}_{3}$ oxide consistent with acceptable mechanical properties, and (b) is it desirable to try to develop corrosion-resistant alloys with low chromium contents, because of uncertainties $\vdots n$ the relations of the U.S. with chromium supplier countries?

Simple sulfidation is only a problem in these heat engines in very special cases. There has been a proposal to use sulfur vapor as the secondary cooling fluid in an engine because of its desirable thermodynamic properties. Such an engine would require a number of alloys resistant to sulfur vapor and liquid at elevated temperatures. If it were decided to proceed with this system, further research on the mechanism of sulfidation of alloys and on the identification of resistant materials should be undertaken.

The rate of metal degradation due to oxidation may be enhanced considerably by the presence of a second oxidant, such as sulfur, carbon, or perhaps chlorine. In most of the heat engine systems, this is most likely to be a problem for the components in contact with the hot combustion products; namely, the exhaust valves and exhaust trains in the case of ICE and diesel engines; the first stage vanes and blades in gas turbines; and heat exchangers in the indirect systems. In all these examples, the principal problem is sul ${ }^{\circ}$ idation/oxidation. It is not yet clear how the minor second oxidant is able to destroy the protective capabilities of the oxide. Following this, the alloy may be rapidly attacked by steps which have been identified and discussed in some detail. The development of improved alloys and coatings would improve system reliability; and, by allowing higher temperatures to be attained, would result in inproved efficiency. There has been a significant amount of work in this field in recent years, and care should be taken to establish how new work would differ form that done before. The opportunities at this moment were said to be rather restricted, but the mechanism of the breakdown of the protective oxide needs additional study. 
The alloys may also suffer accelerated oxidation in the presence of a molten salt. In some cases, where an alkali sulfate is part of the melt, again the actual process is sulfidation/oxidation. In other cases, the salt may dissolve the metal or its normally protective oxide as an anionic or a cationic species, and then reprecipitate it as an oxide at a position remote from the metal surface where it cannot take part in the protection. This is of ten termed "hot corrosion". There has been and continues to be, a considerable interest in this process for gas turbine inlet stages and for heat-exchangers in both oil-fired and coal-fired systems. Extensive work has been done on the mechanism of the reaction. Alloy vendors introduce new alloys resistant to the attack at regular intervals. coating vendors (and the large gasturbinis producers) introduce new coating systems even more frequently. It is difficult to identify additional research opportunities not coverey by the companies themselves, other Federal funding agencies, other jarts of DOE, and other organizations such as EPRI.

In systems burning coal, or ingesting sand with the intake air, there may be an erosion component as well as corrosion, and there may be positive (or negative) synergisms between these. Again, extensive work has been done and is in progress.

Many investigators have suggested that there may be an interaction between the environment and high-temperature mechanical properties, such as creep and fatigue (particularly low-frequency). Systems where carburization is known to take place are suspected as being particularly susceptible. However, no clear case of a failure in practice due to such an interaction seems to have been identified. Some work is in progress, particularly in Europe. Fretting also is experienced in some s./stems and may be enhanced in a corrosive environment. Again, some work is in progress, and further studies should address an identified practical problem and aim at the development of improved materials.

\section{Chemical Processes}

Discussions about chemical processes included processes for the modification of primary fuels by gasification, reforming, 
liquefaction and hydrogenation. Similarly, processes concerned primarily with the production of metals and other materials are subject to corrosion problems that reduce the value of the product, cause recycling, and consequently, cause energy wastage. Processes designed to "recycle" energy, such as incineration and heat recovery, or heat transfer systems also are subject to performance downgrading due to corrosive interactions. Such interactions were said to range from simple high temperature oxidation to complex interactions involving mixed gases, molten salts and erosive particles. Most of the severe corrosive situations were found to belong in the complex interactive systems.

Simple oxidation alone was said to be significant in fireside boilers and reformers. Much already has been accomplished in the understanding of oxidation; however, serious problems remain in the areas of metal-scale adhesion and the effects of active metal additions, such as Ce and $\mathrm{Hf}$, that are seen to improve adhesion. It is possible that the application of new techniques such as acoustic emission testing will allow new insights to be gained in the study of scale adhesion. Similarly, the problems of sulfidation and carburization encountered in atmospheres of low oxygen potential were discussed. Research in these areas is needed to generate a better understanding of corrosion mechanisms together with the development of improved materials to be more resistant to this type of attack. Successful work in these areas would lead to conservation of materials and energy and contribute to the technology base. Research is well supported already and it has a high chance of success.

Corrosion in multicomponent atmospheres is a serious problem in many systems such as gasifiers, heat exchangers, combustors, and incinerators. Some basic understanding of the problem exists but much remains to be done on mechanisins by which the second oxidant transports through protective oxide layers leading to the formation of, typically, sulfides and carbides at the metal surface. This represents an important initiation step in deterioration of the initial scale. closer to practice, work is required to develop alloys or systems that are more resistant to these atmospheres. Specific prograns may be required for 
each complex system. Successful work here would improve fuel flexibility with consequent materials and energy conservation, add to basic understanding and have a high chance of success. Research is already well funded and underway at several centers.

Interactions between metals and molten salts and slags were noted in gasifiers, heat exchangers, and other plants. Not oniy may there be corrosive attack of the metal but also deposit build up that restricts essential heat transfer. Consideration of this complex problen would require explanation of ash agglomeration and definition of conditions under which successful attachment to the metal surfaces occurs initially. The work should also involve a study of oxidation processes occurring simultaneously with heat transfer.

In addition to the mechanistic work above it was thought likely that insufficient basic data were available concerning phase stability, intersolubility, complex compound and liquid formation. Such primary information is necessary if meaningful corrosion mechanisms are to be jenerated.

Erosion-corrosion represents a cooperative degradation mechanism that is found in systems exposed to high temperature, oxidizing gai streams containing particulates. Fundamental work is needed to clarify the mechanisms by which synergistic interactions occur, and also will require eventual consideration of complex atmospheres involving molten salts. Such degradation occurs in fluidized bed combustors, gasifization and liquefaction plants. Due to severe experimental difficulties, work under well defined conditions has only recently been possibe and much remains to be done.

Corrosion of metals under applied stress can frequently be circumvented by using cooled stress-bearing members. A start to investigating this interaction has already been made in Europe. Such investigations, from a fundamental point of view, should yield valuable insigh: into a complex situation.

The interaction of fretting and corrosion also is avoided by good design, as far as possible, but it is still a problem where the proces: itself generates relative movement. Although the economic impact may not be large, research from a fundamental point of view would 
be worthwhile in establishing the basic mechanisms by which chemicalmechanical interaction can lead to enhanced corrosion rates.

\section{Batteries and Fuel Cells--High Temperature}

High-temperature batteries such as the sodiun-sulfur and lithium-sulfur systems; and high temperature fuel cells, such as the molten carbonate and solid oxide systems, were said to be beset with a range of serious corrosion problems. The most serious problems are caused by sulfidation, oxidation, carburization, and molten salt corrosion. To a lesser extent, mixed-oxidant, liquid-metal and creep forms of corrosion are factors to be considered.

Sulfidation of current-collector and cell-container materials is perhaps the most serious corrosion probiem in high temperature batteries. Most metal and alloys are attacked by sulfur/polysulfide melts at $350 \mathrm{C}$ and by iron disulfide at $450 \mathrm{C}$. Metals such as chromium can withstand attack by polysulfides for only about 1 to 2 years. There is a great need to understand the mechanism of liquid-phase sulfidation of metals and alloys, and to identify new alloys and coatings suitable for use in high temperature, high sulfur activity environments. Sulfurbearing species are also detrimental to the stability of all components in molten-carbonate fuel cells, and there is a need to identify practical means to exclude sulfur from the cell compartment, or identify materials that are not sensitive to sulfur-bearing species.

The air electrode and cell-container materials in high teinperature fuel cells are subject to oxidation, and there is a need to identify electrodes and container materials with greater stability.

In the molten carbonate fuel cell, attack by the aggressive carbonate ion leads to the carburization of cell components, and there is a need to characterize this mechanism and identify materials that resist such attack.

In high-temperature molten salt batteries, such as those employing LiCl-KCl, LiCl-LiF-LiBr or NaCl-A1C13 eutectic melts, the molten salt may attack various cell components, such as the electrode materiais, cell containers, seals and feedthroughs. It is necessary to 
understand the mechanism of this attack and identify new materials that are resistant to these molten salt mixtures. For example, it is not clear whether the corrosion occurs via a mixed oxidant/molten salt mechanisin or via a single mechanism.

The seal materials in alkali metal-sulfur batteries are subject to attack by liquid alkali metals, and there is a need to identify seal materials that are stable to these alkali metals, such as lithium.

Various glass materials that have been proposed for use as solid electrolytes in alkali metal-sulfur cells are subject to slow chemical attack by the alkali metal. This attack leads to creep and fatigue of the glass; eventually leading to cell failure. There is a need to understand the mechanism by which the metal attack causes the glass properties to degrade, and to identify new glass compositions that are nore stable to alkali metals.

\section{Electrometallurgical Processes}

Electrometallurgical processes as they are practiced today largely circumvent corrosion problems, but with low energy efficiencies as a consequence. A typical example is the Hall-Heroult process to manufacture aluminum. Consumable carbon anodes are being used because of the lack of oxidation-resistant electrode materials; a metal pool protects the carbon cathode to prevent excessive carbide formation; sidewalls are protected by the frozen bath; and the process is controlled without continuous input from sensors. The resulting cell geometry is unfavorable, with a large anode-cathode distance leading to excessive ohmic losses, and the space-time yie?d is low. New anode and cathode materials (such as oxides, cermets or metal anodes and wettable cathodes) would permit cell design to be changed to reduce energy consumption significantly.

Particular problems to be addressed for the development of advanced cells are: (a) a lack of an understanding of the oxidation of metal and other oxidizable candidate anode materials, and of the facts governing physico-chemical dissolution rates in molten salts: a better 
understanding would lead to more stable non-consumable anodes, (b) a lack of knowledge about the reactions of carbonaceous, refractory hard metal, and refractory materials in the presence of metal and salts: a better understanding would permit cathode and sidewall designs requiring less protection.

Other problems associated with the development of advanced, more energy efficient processes are: (a) corrosion of container materials for chlorides and chlorine in the aluminum chloride and other electrolysis processes, (b) degradation of bipolar electrodes on open circuit, (c) erosion/corrosion of thin-metal-layer electrode substrates, (d) the resistivity increase of contacts between collector bars and cathode carbon, (e) the mechanism of aluminum carbide formation and dissolution, (f) the need for stable construction materials for sensors. Solution of these problems would be of imediate benefit to aluminum production processes.

It was concluded that benefits would be derived mainly from the development of advanced, more energy-efficient electrolys is as a consequence of solving materials problems, rather than from materials conservation in present processes.

Other Systems--High Temperature

A large number of systems exist that operate at high temperatures, but which are not easily classified with any of the other groups. These include high temperature gas cooled reactors (HTGR's), advanced gas reactors (AGR's), breeder reactors (BR's), fusion reactors (FR's), heat pipe systems, filaments for lighting and heating, and hypersonic vehicles (e.g., the space shuttle). Depending upon the system, each suffers from one or more of the degradation mechanisms that have been listed above.

In the case of gas cooled reactors (HTGR's and AGR's) oxidation, carburization, creep, fatigue, and fretting phenomena were all considered to be real or potential problems that require research. Of particular importance is the definition of mechanisms of degradation, and the relationship of these mechanisms with material properties. 
Also, considerable research should be carried out on developing new materials to alleviate these problems in existing and future systems.

In this regard, emphas is should be placed on increasing component reliability, but safety issues must also be addressed. In breeder reactors, the principal problems arise from the interfacing of structural materials with liquid metals (e.g., sodium) and then liquid meta? embrittlement is an issue of major concern. Also, liquid sodium is known to be an effective medium for the transport of material (e.g., other netals), particularly across temperature gradients. Thus, the solubilities of various structural metals and metal compounds in liquid sodium as a function of temperature must be known if the mass transport problein is to be effectively dealt with. Fusion reactors are expected also to have "liquid metal" problems, because of the likely use of a lithium metal blanket for breeding tritium. However, in this case, the tritiuri itself may also cause problems by degrading the mechanical properies of structural materials by a "hydrogen attack" mechanism. The ex:ent to which this may occur, and the severity of the problem if it does; occur, are not know at this time. However, it was concluded that work should not be carried out on this problem until the issue of whether or not fusion reactors will be built is settled.

Erosion/corrosion was identified as being a mechanism of degradation in the case of hypersonic vehicles, such as the space shuttle. Because of the high costs and energy values of these systems, some research is recommended to develop inore erosion-resistant materials for critical surfaces (e.g., leading edges of wings, tail planes). A particl larly important phenomenon in this regard is the degradation of near eicth orbit systems by $W y$-generated atomic oxygen. The mechanistic features of this "space corrosion" process are not well understood, and little work appears to have been carried out on how existing systems and materials (e.g., Al alloys) may be protected.

The most important generic problems were considered to be oxidation and carburization. Oxidation is a major problem in high temperature fluid streams having high oxygen potentials, but also may be a problem on the non-process side where the high temperature metal surface is exposed to air. Carburization usually occurs in those systems that 
contain high temperature gases of high carbor potentials, which may exist, for example, in AGR's in which the coolant is carbon dioxide. In this case, 9 percent $\mathrm{Cr}$ steel is observed to carburize, and this leads to degradation of its mechanical properties. The principal thrust areas for research in oxidation and carburization phenomena should be to develop better understandings of the mechanisms of the processes (low priority) and to develop new materials and coatings (high priority) that may be used to overcome the problems in practical systems.

\section{Corrosion Control and Prevention}

To facilitate collating research needs, the discussions focused on (1) materials, (2) coatings, (3) design, (4) monitoring, (5) control of the environment, (6) electrochemical protection methods and (7) technology transfer.

Materials

The need to develop new corrosion resistant alloys containing less of the strategic elements, such as chromium, was identified. Increased use of stabilized stainless steels, such as Type 347 could help alleviate some of this problem.

In order to conserve fuel in the transportation sector, the need to develop high strength, corrosion resistant aluminum and titanium alloys was discussed.

Much research is under way now on developing amorphous, and microcrystalline alloys using rapid solidification techniques. Some preliminary data show that some of these alloys have improved corrosion resistance in certain environments, such as better resistance to crevice corrosion, or comparable resistance to general attack with lower chromium content. There is a need to conduct experiments to characterize these materials, and establish a data base to make the information available.

Some ceramic and polymeric materials are resistant to corrosion attack in a variety of environments. Methods of fabrication into 
structures or application as coatings should be studied, and property determinations made as needed. Materials of interest include carbides, nitrides and silicides, polycarbonates, polyfluoroethylenes, nylons and mineral-filled plastics.

\section{Coatings}

As briefly mentioned above, there is a need to investigate the bonding of polymeric, ceramic and composite materials to metals. The latter provides the structure with desirable mechanical properties, while the coatings provide the corrosion resistance. Similarly, there is a need to develop metallic coatings highly resistant to corrosion and/or erosion for application to low cost substrate metals, which have the necessary mechanical properties, or which can be more easily fabricated. Electroless $\mathrm{Ni}-\mathrm{P}$ or $\mathrm{Ni}-\mathrm{B}$ alloys serve such a function, but the deposition process is slow, and the plating baths are not very stabie, hence present a waste treatment probiem. Electrolytic coatings, such as multilayer $\mathrm{Cu}+\mathrm{Ni}+\mathrm{Cr}$, are well established but further work is needed on eleztrodepositing stainless steel type alloys as thick coatings. Laser remelting and laser alloying are other approaches which may find application in certain circumstances where cost is not a critical factor. The same may be said for other sophisticated coating processes such a; vapor deposition and ion implantation.

of a more practical nature is the corrosion problem experienced in flue gas desulfurization systems. Even stainless steels and nickel alloys give poor performance. A possible solution is the use of organil: coatings on carbon steel for the scrubbers. Some work is under way evaluating fluorocarbon and vinyl ester coatings. The former works well it: properly cured, while the latter works well but cannot stand therma shocks. Studies are needed to improve the method of solvent remova form the fluorocarbons, and to improve the mechanical properties of the vinyl ester coating. Multilayer coatings may also provide satisfactory performance. 
Design

Improved designs to minimize corrosion have been proposed for many years; however, examples of poor design still occur, especially where design, materials and corrosion engineering functions are not integrated. Design for protection or control should encompass removing crevices, minimizing welds and reducing stresses. With the advent of computer aided design and manufacturing equipment and expertise, there is a good opportunity now to develop advanced stress analys is methods, document sound design principles and combine these with a materials performance technology data base to provide a computerized service and handbooks.

\section{Monitoring}

Many detection and monitoring devices and allied instrumentation are needed to reduce materials wastage through corrosion. While some work has been done on "pigs" for detecting cracks in pipelines, a wide range of instrumentation is needed for detecting:

- crack size

- crack growth rates

- corrosion rates (general)

- localized oH

- localized solution chemistry

- localized soil chemistry

- localized activity of $\mathrm{O}_{2}, \mathrm{CO}_{2}, \mathrm{CO}$, etc.

- localized stresses

- true cathodic protection potentials.

If such properties could be determined in real time, there might be the opportunity for feedback and control. At least important data would be obtained for input into corrosion models as they are developed.

As an example, organic coatings are used in duct work or other locations where miid corrosion protection is required. Often these coatings are in inaccessible locations. It would be helpful if a sensor were available that could be installed at the coating/metal interface to 
be activated remotely to provide information on the presence of an aqueous phase at the interface; local pH; permeability to environmental constituents; and perhaps the physical condition of the coating also.

Environmental Control

If the material and/or coating cannot be optimized, there exists the possibility to modify and control the environment to make it less aggressive. Topics that received consideration were the need for effective, low cost substitutes for common salt for deicing roads; low cost substitutes for chromate inhibitors; and the need to elucidate the combined role of organic and inorganic contaminants in corrosion systems.

\section{Electrochemica! Protection Methods}

The use of anodic protection is not as widespread as cathodic protection, although in some circumstances it might have beneficial effects such as the control of microbiological corrosion. Anodic protection often involves the establishment of $10 \mathrm{w} \mathrm{pH}$ environments locally and there is a need to develop inhibitors or coatings stable under this condition. In the area of cathodic protection, guidelines for specific applicitions need to be established (such as bridges, underground storage tanks) and the role of stray current corrosion must be better understood.

\section{Technology Transfer}

Discussion focussed on the need to take control and prevention methods developed for certain circumstances and apply them to similar problems in other sectors. Conversely, there is also the need to document and report failures so that others do not make the same mistakes. Examples of such technology transfer might include (1) more widespread use of titanium alloys, (2) improper use of lubricants, (3) wider use of corrosion models and fracture mechanics theory, and (4) new uses for existing coating technology. 


\section{PRIORITIZED RESEARCH NEEDS}

\section{Screening Procedures}

During the technical group discussions many specific research needs were identified and tabulated for screening. The screening and prioritization procedures consisted of the following steps:

(1) providing an identification number for each need

(2) screening of needs according to whether or not they met the general criteria

(3) screening of needs according to specific criteria

(4) calculating the figure of merit for each research need and tabulating the results

(5) integration of the results of the above for each technical discussion group into a prioritized ranking of research needs for corrosion control and prevention in energy conservation systems.

The general criteria applied pertained to the mission of the Department of Energy, Office of Conservation and Renewable Energy; namely, did the identified needs:

- promote fuel flexibility

- conserve energy or materials (provide resource optimization)

- enhance the technology base

- facilitate transfer of technology (between universities and industry).

If the need satisfied at least the first or second criterion given above, it was considered for further discussion and subjected to the specific criteria for evaluation.

The specific criteria applied were concerned with the implications of funding of the research needs so identified. The four criteria used were as follows:

- Urgency, or time to benefit

- Impact on energy conservation systems 
- Probability of success

- Contribution to the technology base.

Ranking numbers were assigned to the specific criteria as shown below for the purpose of computing a relative figure of merit.

Urgency

Impact

Success

Contribution $\frac{\text { Near }(<5)}{3}$

$\frac{\text { Large }}{3}$

$\frac{\text { High }(>50)}{3}$

$\frac{\text { Large }}{3}$ $\frac{\text { Mid }(5-10)}{2}$

$\frac{\text { Medium }}{2}$

$\frac{\text { Medium (25-50) }}{2}$

$\frac{\text { Medium }}{2}$
Long Term $(>10$ years $)$

$\frac{\text { Small }}{1}$

$\frac{\text { LOW }(<25 \%)}{1}$

$\frac{\text { Sma!l }}{1}$

Each research need was assigned a number for each of the four criteria by the members of the technical discussion groups. These numbers were then multiplied by each other to generate a score or figure of merit, which ranged from 1 (for a research need considered not to be urgent, to have a relatively small impact, to have a low probability of successful completion if funded, and to contribute relatively little to the technology data base) to 81 (for a need that urgently needs funding, which would have a large impact on conservation, that has a high probability of successful completion, and that would make a significant contribution to the data base).

This arbitrary method of obtaining a score for each research need was chosen for expediency, and to separate the numerous suggestions for prioritization. During the workshop there were some small variations among the technical groups as to how the scores were computed. One group used a weighting system. In addition, another group a lso included in their screening criteria another factor, i.e., whether the research should be funded by the government, industry, academia, or a combination of these. However, for the purposes of this report the scores have been normalized for each technical discussion group using the scoring procedure described above. 
Ranking of Research Needs

General Corrosion

Of the numerous needs initially discussed, 16 passed the general criteria and were subjected to the ranking procedure. Table D-1 in Appendix 0 lists these needs in order of their score. No editing has been done; thus, some of the suggestions made may seem more appropriate for other discussion groups. Such anomalies are accounted for when the research needs are prioritized.

Localized Corrosion

Table D-2 summarizes the 39 research needs that passed the screening criteria in order of their figure of merit. As with the input from the other technical discussion groups, the research needs are presented without editing or re-assignment to other groups that might appear to be more appropriate for the subject matter concerned.

\section{High Temperature Corrosion}

Some 63 research needs passed the general screening criteria and were subsequentiy assigned a figure of merit. These needs are summarized in Table 0-3. While many needs received a relatively low score, they have been included in the table for the sake of completeness.

\section{Corrosion Control and Prevention}

The 12 highest scoring research needs are documented in Table D-4 in Appendix D. Individual scores for the other research needs discussed and screened were not available, hence, they have not been included in this report. 
Prioritization of Research Needs

In order to integrate the ranked research needs from the four technical discussion groups an arbitrary division into three groups was made. These groups represent the highest ranked needs, the lowest ranked needs, and those which fell in between. The figures of merit corresponding to these groups are as follows:

\begin{tabular}{|c|c|c|}
\hline Score* & $\begin{array}{l}\text { Figure } \\
\text { of Merit } \\
\end{array}$ & Priority Grouping \\
\hline $\begin{array}{l}1111 \\
1112 \\
1113 \\
1122 \\
1123 \\
1222 \\
1133 \\
1223\end{array}$ & $\begin{array}{c}1 \\
2 \\
3 \\
4 \\
6 \\
8 \\
9 \\
12\end{array}$ & Low Priority \\
\hline $\begin{array}{l}2222 \\
1233 \\
2233 \\
1333\end{array}$ & $\begin{array}{l}16 \\
18 \\
24 \\
27\end{array}$ & Mediuin Priority \\
\hline $\begin{array}{l}2233 \\
2333 \\
3333\end{array}$ & $\begin{array}{l}36 \\
54 \\
81\end{array}$ & High Priority \\
\hline $\begin{array}{l}\overline{\text { *Indiv }} \\
\text { any } p \\
2=1\end{array}$ & $\begin{array}{l}\text { scores } \\
1 \text { ar spe } \\
121,12\end{array}$ & $\begin{array}{l}\text { to indicate } \\
\text { erion, e.g., }\end{array}$ \\
\hline
\end{tabular}

It should be pointed out that, although only the research needs falling into tine "high" and "medium" groupings were considered during integration of the findings of the 4 groups, the needs falling into the "low" priority group should not be disregarded entirely. Under some circumstances it may be appropriate to fund some of these ideas, either with governnent monies, or through the industrial sector.

Using the prioritization criterion, 6 needs from the general corrosion group fell into the high priority category, white 8 fell into the melium priority category. Of the needs identified by the localized 
corrosion group, 17 fell into high priority, and 15 fell into the medium priority classifications. High priority needs totalled 14 for the high temperature corrosion group, compared with 8 which fell into the medium priority category. Finally, 6 and 5 needs from the corrosion control and prevention group fell into the high and medium priority categories, respectively.

Tab?e 1 lists all the research needs considered to be high priority, while Table 2 lists all the medium priority research needs. For the sake of consistency, needs with the same figure of merit are listed in the order of presentation of the findings of the technical discussion groups, namely:

- general

- Tocalized

- high temperature

- control and prevention.

Similar needs have been combined where appropriate when Tables 1 and 2 were compiled. Each need having a given figure of merit should be considered to be equal to all others having the same figure of merit for the purposes of evaluating their relative importance.

\section{CONCLUSIONS}

Research needs for the control and prevention of corrosion in energy conservation systems have been identified and screened for their relative importance. The consensus of the workshop participants was that the Government could serve a useful role in sponsoring R\&D on some of the needs considered to be of higher priority.

An inspection of Tables 1 and 2, which 1 ist the high and medium priority needs, respectively, shows that many of these needs may be grouped together in terms of corrosion phenomena (such as pitting or stress-corrosion cracking) or sector or system (such as transportation or chemical processes). Table 3 summarizes the prioritized research needs by corrosion phenomena involved using the identification (I.D.) 
TABLE 1. RESEARCH NEEDS CONSIDERED TO HAVE THE HIGHEST PRIORITY FOR FUNDING

\begin{tabular}{|c|c|c|}
\hline Score & $\begin{array}{l}\text { I.D. } \\
\text { No. }\end{array}$ & Brief Description of Research Need \\
\hline 81 & 1 & $\begin{array}{l}\text { Design, develop a corrosion data base to include } \\
\text { effects of specific environments }\end{array}$ \\
\hline 81 & 2 & $\begin{array}{l}\text { Develop a data base for pitting corrosion and make } \\
\text { avaitable to those who should have the information }\end{array}$ \\
\hline 81 & 3 & $\begin{array}{l}\text { Develop a data base for crevice corrosion and make } \\
\text { available to those who should have the information }\end{array}$ \\
\hline 81 & 4 & $\begin{array}{l}\text { Obtain a better understanding of the mechanism(s) of } \\
\text { crevice corrosion }\end{array}$ \\
\hline 81 & 5 & $\begin{array}{l}\text { Study the effect of minor impurities on intergranular } \\
\text { corrosion }\end{array}$ \\
\hline 54 & 6 & Develop "expert systems" on general corrosion \\
\hline 54 & 7 & $\begin{array}{l}\text { More fundamental studies of the corrosion of steel in } \\
\text { concrete }\end{array}$ \\
\hline 54 & 8 & $\begin{array}{l}\text { Evaluate existing and new alloys for their resistance } \\
\text { to corrosion fatigue, and study role of aggressive } \\
\text { anions }\end{array}$ \\
\hline 54 & 9 & $\begin{array}{l}\text { Evaluate use of anodic protection for preventing or } \\
\text { controlling stress-corrosion cracking }\end{array}$ \\
\hline 54 & 10 & $\begin{array}{l}\text { Study stress-corrosion cracking of Alloy } 600 \text { in } \\
\text { pressurized water reactor applications }\end{array}$ \\
\hline 54 & 11 & $\begin{array}{l}\text { Obtain better understanding of localized solution } \\
\text { chemistry in crevice corrosion }\end{array}$ \\
\hline 54 & 12 & $\begin{array}{l}\text { Establish a corrosion fatigue data base and disseminate } \\
\text { information }\end{array}$ \\
\hline 54 & 13 & $\begin{array}{l}\text { Study mechanism(s) of molten salt corrosion in heat } \\
\text { engines }\end{array}$ \\
\hline 54 & 14 & $\begin{array}{l}\text { Improve alloys and coatings to resist molten salt } \\
\text { corrosion in heat engines }\end{array}$ \\
\hline
\end{tabular}


TABLE 1. (Continued)

I.D.

Score No.
Brief Description of Research Need

$54 \quad 15 \quad$ Study mechanism(s) of molten salt corrosion in chemical processes

$54 \quad 16 \quad$ Study mechanism(s) of molten salt corrosion in fuel cells and batteries

$54 \quad 17$ Study mechanism(s) of molten salt corrosion in electrometallurgical processes

$54 \quad 18$ Study mechanism(s) of molten salt corrosion in heat pipes and heater elements

$54 \quad 19$ Develop alloys which conserve strategic materials and increase the use of ferritic and martensitic stainless steels

5420 Develop criteria for cathodically protecting specific structures, such as bridge decks

$5421 \quad$ Expand the use of anodic protection to control

microbiological corrosion and stress-corrosion cracking

3622 obtain a better understanding of fatigue and stress related failures on the infrastructure (roads, bridges, etc.)

3623 Develop new instruments and non-destructive testing methods to detect corrosion

3624 More fundamental studies on automobile corrosion and protection approaches

3625 Develop models and better experimental techniques to study pitting corrosion of aluminum

3626 Solve problem of intergranular corrosion of gas diffusion electrodes

3627 Obtain better data on the intergranular corrosion of Inconel ${ }^{\text {बi }}, \mathrm{Ti}, \mathrm{Al}$, etc. 
TABLE 1. (Continued)

I.D.

Score No. Brief Description of Research Need

3628 Determine mechanism(s) of intergranular attack and contribution, if any, to stress-corrosion cracking

3629 Develop pore-free Ti coatings for dimensionaliy stable electrodes

$3630 \quad$ Develop materials immune to more than one form of corrosion attack

3631 Develop a model to predict, diagnose and prevent stress-corrosion cracking failures

3632 Determine extent of problem with stress-corrosion cracking in sour gas wells

$3633 \quad$ Investigate effect of surface modification by alloying on crevice corrosion

$3634 \quad$ Develop improved materials to resist molten salt corrosion in chemical process industries

$36 \quad 35 \quad$ Develop improved materials and coatings for resisting molten salt corrosion in fuel cells and batteries

$3636 \quad$ Improve corrosion resistance of materials to resist molten salt corrosion in electrometallurgical processes

$3637 \quad$ Develop improved materials to resist molten salt corrosion for use in heat pipes and heater elements

$36 \quad 38 \quad$ Develop improved refractories to resist liquid meta1 attack in chemical processes

$3639 \quad$ Modify processes to restrict contact between liquid metals and refractories in chemical processes

3640 Develop alloys and coatings for heat engines to resist erosion-corrosion

3641 Develop alloys and coatings for chemical process equipment to resist erosion-corrosion 
TABLE 1. (Continued)

$\begin{array}{lll}\text { Score } & \begin{array}{l}\text { No. } \\ \text { No. }\end{array} & \text { Brief Description of Research Need } \\ 36 & 42 & \begin{array}{l}\text { Develop electrochemical instrumentation for failure } \\ \text { analysis and detection }\end{array} \\ 36 & 43 & \begin{array}{l}\text { Find less corrosive de-icers for highway use } \\ \text { Study effect of trace amounts of contaminants on } \\ \text { cracking phenomena and develop removal methods }\end{array}\end{array}$


TABLE 2. RESEARCH NEEDS CONSIDERED TO HAVE MEDIUM PRIORITY FOR FUNDING

\begin{tabular}{|c|c|c|}
\hline Score & $\begin{array}{l}\text { I.D. } \\
\text { No. }\end{array}$ & Brief Description of Research Need \\
\hline 27 & 45 & Develop a test for detecting corrosion fatigue \\
\hline 27 & 46 & $\begin{array}{l}\text { Increase the data base for use of } T i \text { alloys as } \\
\text { substitutes for highly alloyed stainless steels and } \\
\text { nickel alloys }\end{array}$ \\
\hline 27 & 47 & $\begin{array}{l}\text { Provide technology transfer for existing methods to new } \\
\text { applications }\end{array}$ \\
\hline 27 & 48 & $\begin{array}{l}\text { Provide technology transfer on the correct use of } \\
\text { materials and their substitution }\end{array}$ \\
\hline 27 & 49 & Develop less corrosive road de-icer materials \\
\hline 24 & 50 & $\begin{array}{l}\text { Study roles of passivation, depassivation and } \\
\text { repassivation in crevice corrosion }\end{array}$ \\
\hline 24 & 51 & $\begin{array}{l}\text { Study methods to prevent filiform corrosion in } \\
\text { photovoltaic devices }\end{array}$ \\
\hline 24 & 52 & $\begin{array}{l}\text { Develop a test for detecting exfoliation corrosion } \\
\text { propensity for Al alloys }\end{array}$ \\
\hline 24 & 53 & $\begin{array}{l}\text { Study mechanism(s) of cavitation corrosion and develop } \\
\text { control methodology }\end{array}$ \\
\hline 24 & 54 & $\begin{array}{l}\text { Develop a test methodology to study corrosion by molten } \\
\text { salts in electrometallurgical processes }\end{array}$ \\
\hline 24 & 55 & $\begin{array}{l}\text { Study mechanism(s) of carburization in chemical process } \\
\text { equipment }\end{array}$ \\
\hline 24 & 56 & Study mechanism(s) of carburization in fuel cells \\
\hline 24 & 57 & $\begin{array}{l}\text { Study mechanism(s) of carburization in other } \\
\text { conservation systems }\end{array}$ \\
\hline 18 & 58 & $\begin{array}{l}\text { Develop models relating corrosion control and } \\
\text { protection to environmental factors }\end{array}$ \\
\hline 18 & 59 & $\begin{array}{l}\text { Obtain a better understanding of the effectiveness of } \\
\text { cathodic protection systems }\end{array}$ \\
\hline
\end{tabular}


TABLE 2. (Continued)

\begin{tabular}{|c|c|c|}
\hline Score & $\begin{array}{l}\text { I.D. } \\
\text { No. }\end{array}$ & Brief Description of Research Need \\
\hline 18 & 60 & $\begin{array}{l}\text { Develop specifications for government construction } \\
\text { projects }\end{array}$ \\
\hline 18 & 61 & $\begin{array}{l}\text { Evaluate in more detail the impact of the environment } \\
\text { on the corrosion of metals }\end{array}$ \\
\hline 18 & 62 & $\begin{array}{l}\text { Study materials related problems in oil recovery } \\
\text { processes }\end{array}$ \\
\hline 18 & 63 & $\begin{array}{l}\text { Study role of corrosion and fatigue in corrosion } \\
\text { fatigue }\end{array}$ \\
\hline 18 & 64 & Study role of fouling in initiating pitting corrosion \\
\hline 18 & 65 & $\begin{array}{l}\text { Provide documentation on effectiveness of cathodic } \\
\text { versus anodic protection to control pitting }\end{array}$ \\
\hline 18 & 66 & $\begin{array}{l}\text { Study stress-corrosion cracking of Type } 304 \text { stainless } \\
\text { steel in boiling water reactors }\end{array}$ \\
\hline 18 & 67 & $\begin{array}{l}\text { Study low temperature chloride cracking of stainless } \\
\text { steels }\end{array}$ \\
\hline 18 & 68 & Find inhibitors to prevent crevice corrosion \\
\hline 18 & 69 & Develop monitors to detect crevice corrosion \\
\hline 18 & 70 & Improve resistance of $\mathrm{Ti}$ to exfoliation corrosion \\
\hline 18 & 71 & Study mechanism(s) of erosion-corrosion in heat engines \\
\hline 18 & 72 & $\begin{array}{l}\text { Study mechanism(s) of erosion-corrosion in chemical } \\
\text { process equipment such as fluidized bed combustors }\end{array}$ \\
\hline 18 & 73 & $\begin{array}{l}\text { Use surface modification techniques to develop low } \\
\text { cost, corrosion resistant materials or coatings }\end{array}$ \\
\hline 18 & 74 & $\begin{array}{l}\text { Develop in situ techniques for detection and } \\
\text { measurement of crack growth }\end{array}$ \\
\hline 18 & 75 & $\begin{array}{l}\text { Study effects of relative areas of cathodes and anodes } \\
\text { on the corrosion of steel rebars in concrete }\end{array}$ \\
\hline
\end{tabular}


TABLE 2. (Continued)

\begin{tabular}{lll}
\hline Score & $\begin{array}{c}\text { I.D. } \\
\text { No. }\end{array}$ & \multicolumn{1}{c}{ Brief Description of Research Need } \\
\hline 16 & 76 & $\begin{array}{l}\text { Solve corrosion problems with ambient temperature fuel } \\
\text { cells and batteries }\end{array}$ \\
16 & 77 & $\begin{array}{l}\text { Study mechanism(s) or erosion-corrosion of cathodes } \\
\text { used for Al electrowinning }\end{array}$ \\
16 & 78 & $\begin{array}{l}\text { Study mechanism(s) of erosion-corrosion in hypersonic } \\
\text { vehicles } \\
\text { Develop temporary passivation method for calcium } \\
\text { battery electrodes }\end{array}$ \\
\hline \hline
\end{tabular}


TABLE 3. PRIORITIZED RESEARCH NEEDS LISTEU ACCORDING TO CORROSION PHENOMENA INVOLVED

\begin{tabular}{ll}
\hline \multicolumn{1}{c}{ Corrosion Phenomenon } & \multicolumn{1}{c}{ Research Need I.D. Number* } \\
\hline Anodic Protection & $9,21,65$ \\
Carburization & $55,56,57$ \\
Cathodic Protection & $20,59,65$ \\
Cavitation & 53 \\
Corrosion Fatigue & $8,12,22,45,63$ \\
Crevice Corrosion & $3,4,11,33,44,50,68,69$ \\
Erosion-Corrosion & $40,41,71,72,77,78$ \\
Exfoliation & 52,70 \\
Filiform Corrosion & 51 \\
Intergranular Attack & $5,26,27,28,74$ \\
Liquid Metal Attack & 38,39 \\
Molten Salt Attack & $13,14,15,16,17,18,34,35,36,37,54$ \\
Pitting Attack & $2,25,29,64,65,75$ \\
Stress-Corrosion Cracking & $9,10,22,31,32,74$ \\
\hline
\end{tabular}

* From Tables 1 and 2 . 
TABLE 4. PRIORITIZED RESEARCH NEEDS LISTED ACCORDING TO PRINCIPAL SECTOR OR SYSTEM INVOLVED

\begin{tabular}{|c|c|}
\hline Sector or System & Research Need I.D. Number* \\
\hline Batteries and Fuel Cells & $\begin{array}{l}2,4,5,11,16,25,33,35,50,56, \\
68,69,73,76,79\end{array}$ \\
\hline Buildings and Structures & $\begin{array}{l}2,3,4,6,7,8,9,11,12,20,21, \\
22,25,33,43,49,50,53,60,68,69, \\
75\end{array}$ \\
\hline Chemical Processes & $\begin{array}{l}2,3,4,6,9,15,18,25,26,27,29, \\
33,34,37,38,39,41,45,50,52,53, \\
55,64,65,68,69,70,72,73\end{array}$ \\
\hline Electric Power Generation & $5,10,27,37,51,64,66,67,68,69$ \\
\hline Electrometallurgical Processes & $5,6,17,36,54,77$ \\
\hline Heat Engines & $5,13,14,54,71$ \\
\hline $\begin{array}{l}\text { Geotherisal and 0ther Energy } \\
\text { Energy Conversion }\end{array}$ & $\begin{array}{l}2,3,4,6,11,18,30,32,33,37,50, \\
51,62,68,69\end{array}$ \\
\hline Transportation & $\begin{array}{l}2,3,4,5,6,8,11,12,21,24,25, \\
33,43,45,46,49,50,52,53,60,63, \\
68,69,70,78\end{array}$ \\
\hline A11 Sectors & $\begin{array}{l}1,19,23,28,30,31,42,44,46,47, \\
48,57,58,59,60,61,67,73,74\end{array}$ \\
\hline
\end{tabular}

*From Tables 1 and 2. 
number given in Tables 1 and 2. Similarly, Table 4 summarizes the research needs by sector or system, also using the I.D. numbers associated with each in Tables 1 and 2 .

Other classification methods are possible. Because no single method is capable of including all the research needs presented in Tables 1 and 2, it is appropriate to summarize below some general topic areas, in alphabetical order, which are recominended for consideration for funding by the Department of Energy, Office of Conservation and Renewable Energy because they apply to two or more of the sectors discussed earlier.

Selection of specific needs within each of the following topics will depend on a number of factors, the identification of which was beyond the scope of the workshop. For example, it may be approprite for industry to cost share in some of the research programs, while in some circumstances industry may choose to fund some research needs entirely independently because of pressing needs. In general, it was felt that the role of Government should be to sponsor research on needs associated with a high risk but having a broad range of applicability to Government and industry if successful, and a large impact on conservation of energy and materials.

\section{Anodic and Cathodic Protection}

Because a greater experience has been gained with cathodic protection, research needs for anodic protection systens received a higher priority ranking in general.

Work should be done to evaluate the applicability of anodic protection for preventing or controlling stress-corrosion cracking and microbiological corrosion. Some preliminary studies are under way in industry to investigate the use of anodic protection for controlling stress-corrosion cracking, but there is a problem with finding suitable reference electrode systems. In a broader sense there is a need to provide documentation on the effectiveness of anodic versus cathodic protection so that users can make more educated choices. 
With respect to cathodic protection, one specific need is the development of criteria for the effective protection of certain structures such as pipelines and bridge decks. Finally, there is an apparent need to obtain a better understanding of the effectiveness of cathodic protection systens in general, and to provide better instrumentation for their control.

\section{Carburization}

Considered to be of medium priority is the need to study the mechanisms responsible for this phenomenon in (1) chemical process equipment, (2) fuel cells, especially with molten salt (carbonate) electrolytes, and (3) other conservation systems where the environments contain a low partial pressure of oxygen, a relatively high carbon activity, and these are present at elevated temperatures. The problem of carburization is particularly severe in the area of hydrocarbon processing.

\section{Cavitation}

A need was expressed to obtain a better understanding of the mechanism(s) for cavitation corrosion. Prior research suggested that this phenomenon was largely the result of the action of mechanical forces tue to collapsing bubbles in a liquid environment, e.g., a propeller screw in sea water. Some recent modelling work has shown that electrokinetic effects could produce large, localized currents that might be responsible for the corrosion attack. Thus, further work would help resolve which hypothesis is correct. The effort was considered to be of medium priority.

\section{Coatings}

The use of improved coatings to control or prevent corrosion was a common theme throughout the discussions, and several examples have 
been given in the review of the technical discussion group findings. Much work is currently under way; therefore, many of the needs were classified as being of low priority. However, one research need did receive a high priority ranking. This was the need to develop pore-free coatings for the titanium dimensionally stable anodes used in the chloralkali industry. Such coatings would extend their useful life considerably.

A medium priority research need was the study of the use of surface modification techniques to develop low cost, corrosion resistant coatings or materials. Amorphous ("glassy") or microcrystalline materials have demonstrated several interesting properties including increased resistance to pitting and crevice corrosion.

\section{Corrosion Fatigue}

Three research needs were considered to merit high priority for funding. Work should be done on evaluating existing and newly developed alloys for their resistance to corrosion fatigue in a variety of environments, and to study the effect of aggressive anions on initiating failure. A better understanding should be obtained of the causes of fatigue and stress related failures on the nation's infrastructure, which includes roads, bridges, pipelines, buildings and other structures. Finally a need was seen for establishing a data base and disseminating the information to those who have a need for it.

Medium priority needs to be considered for funding are the development of a test to detect incipient corrosion fatigue failures, or the combination of factors that could lead to corrosion fatigue; and a study to determine the relative importance of corrosion and fatigue in contributing to this phenomenon.

\section{Crevice Corrosion}

Crevice corrosion, along with pitting attack, was considered to be one of the more serious forms of materials degradation because it often results in catastrophic failures. Consequently, several research 
needs were classified as being of high priority. Work is needed to obtain a better understanding of the mechanism(s) of crevice corrosion in a wide variety of environments, and this should include studies of the localized solution chemistry responsible for failures. The role of trace anlounts of contaminants should be established and means found for removing them. Finally, the effect of surface modification by alloying should be investigated as a preventative measure. Subsequently, a data base should be established and made available to engineers, designers and others with a need to know.

There were three medium priority research needs in the area of crevice corrosion. Work was proposed on studying the role of passivation, depassivation and repassivation on the propagation of this type of attack. Related work should involve studying the feasibility of using inhibitors to control local solution chemistry and film forming ability of the nietals. Finally, monitors should be developed to detect the onset of crevice corrosion, or at least identify the existence of conditions conducive to leading to this type of corrosion failure.

\section{Erosion-Corrosion}

The development of alloys and coatings to resist erosioncorrosion in chemical process equipment and heat engines should receive high priority. Specific problem areas include the inlet stages of coalfired turbines; in coal-fired boilers; and in rocket nozzles; in the let-down stages of liquefaction plants; in gasification processes, especially fluidized bed systems; and in fluidized bed combustors.

More important in the longer term, and thus receiving only medium kriority rankings, were the identified needs to study the mechanisms of erosion-corrosion in (1) heat engines, (2) chemical process equipment, (3) hypersonic vehicles, such as the space shuttle, and (4) electrometallurgical processes, particularly cathodes used for electrowinning aluminum. 


\section{Exfoliation and Intergranular Attack}

A test should be developed to detect the susceptibility of aluminum alloys to exfoliation, or to detect the initial stages of such attack. Developing such a test was considered to merit medium priority. Similarly, in situ techniques should be developed to detect and measure crack growth, both intergranular and transgranular, in a range of alloys to support development studies. A need was identified to develop titanium alloys more resistant to exfoliation so that they could be used more widely in plants and structures.

of higher priority, according to the criteria used, were studies to determine the effect of minor alloying constituents or impurities on intergranular corrosion; and to elucidate the mechanism(s) of such attack. Work should determine if intergranular attack is a precursor to stress-corrosion cracking, and if so what is its relative importance in systems of interest. A general need is to obtain better data on this phenomenon, and resistance to attack by such important materials as Incone $7^{\text {e }}$, titanium and aluminum.

\section{Liquid Metal Attack}

Two needs should be considered for funding. One is the development of improved refractories to resist 1 iquid metal attack in the chemical process industries. The other is to modify chemical processes to restrict the contact between liqdid metals and refractories; thus, alleviating this corrosion problem. Both needs received a high priority ranking.

\section{Molten Salt Attack}

Research should be conducted on establishing the mechanisms of molten salt attack of (1) heat engines; in (2) chemical processes, (3) electrometallurgical processes; and of (4) heat pipes and heater elements. As complementary programs, work should be done on developing improved materials to resist such corrosion in (a) chemical process 
equipment, (b) fuel cells and batteries, (c) electrometallurgical process equipment, and for (d) heat pipes and heater elements. Specific problem areas considered to be of high priority were the exhaust trains in heat engines; the first stage in turbines; in heat exchangers; and in heat pipes used in thermionic power generators. In the chemical and electrometallurgical process industries coatings or improved materials are needed for gasification equipment, burners, continuous smelting equipment, anodes, containers and sensors. In high temperature fuel cells and batteries, problem areas are associated with containers, seals, current collectors and solid electrolytes.

The above were ranked among the high priority needs. Among the medium priority needs was the recognition that a test methodology was nesded for studying molten salt corrosion in electrometaliurgical proces'ses.

\section{Pitting Attack}

Better models are needed to explain pitting phenomena, and improved experimental techniques are required to study pitting corrosion, oarticularly of aluminum alloys. Such research should receive high priority, along with establishing a data base and making the infor-

mation available to those that need it, including architects, designers, corrosion engineers, plant engineers and the like.

of medium priority, but nonetheless important, is the need to evaluate the role of fouling in initiating pitting corrosion, particularly in heat exchangers and marine environments. Documentation is needed on the role of anodic or cathodic protection for controlling pitting attack.

\section{Strategic Materials Substitution}

Coatings or surface modification of metals have already been discussed, and can be viewed as one means for substituting more readily available materiais for strategic or critical materials, such as nicke? 
and chromium. One high priority research need identified was the development of alloys that conserve such materials. More widespread use of ferritic and martensitic type steels could accomplish this objective. Also, it was recommended that the data base be expanded for the use of titanium alloys as substitutes for highly alloyed stainless steels and nickel alloys. The latter was considered to merit only medium priority for funding consideration.

\section{Stress-Corrosion Cracking}

Stress-corrosion cracking, and related phenomena, also were judged to be important corrosion processes in terms of the types of failure encountered. Therefore, it is important to develop models to predict, diagnose and help prevent stress-corrosion cracking. The role of anodic protection in controlling stress-corrosion cracking in the chemical process industries also should be determined. Other specific topics receiving a high priority ranking were (1) the need to study the cracking of Alloy 600 in pressurized water reactor applications, (2) determining the extent of the problem in sour gas wells, and

(3) obtaining a better understanding of stress-related failures on the nation's infrastructure, as defined earlier. Techniques should be developed to detect and measure crack growth in situ.

\section{Tests and Instrumentation}

Besides specific test or instrumentation requirements already given above, several, more general needs were identified. Receiving high priority ranking were the development of electrochemical instrumentation for failure analysis and corrosion detection. Other nondestructive methods for detecting corrosion would also find widespread application, especially in the nuclear energy field and gas distribution systems. Application of corrosion probes to roads, bridges, railroads, buildings, process plant and other structures, for exampie, could identify flaws or the initiation of dangerous forms of corrosion. Remedial actions could then be taken before serious failures occurred, and expensive repairs were necessary. 
Lower priority research needs included the development of a monitor to detect the onset of crevice corrosion, and in situ methods for the detection and measurement of crack growth.

\section{General Corrosion}

Two important areas were identified for funding consideration, namely the corrosion of steel in concrete, and corrosion of automobiles. There is still room for fundamental and applied studies on corrosion in both trese areas, and on protective measures that would prove effective.

With respect to the corrosion of steel in concrete, work is needed on investigating the influence of new cement formulations, and refererce electrodes are needed for cathodic protection systems. Inexpensive, but satisfactory coatings are required for the reinforcing bars, i.e., coatings that can withstand rough handling, storage, transportation, installation without developing holidays or other defects.

Concerning automobiles, work is needed to not only improve the corrosion resistance of personal automobiles, vans and commercial vehicles, but also work is needed to increase the durability of government owned vehicles, including the military. Research should be focused on identifying corrosion mechanisms through an analysis of the corrosion products, then specifying preventative measures.

In the transportation sector, a need that could have significant impact on reducing the cost of corrosion is the requirement for alternative, less corrosive, low cost road de-icers to replace salt. Although work has been done, all the alternatives to date have been too expensive for widespread use on highways, streets, parking lots, and so on.

\section{Corrosion Data Base}

Finally, as may have become apparent from the above discussions, there is an urgent need to provide data bases on specific corrosion phenomena, control practices, and on materials of construction. Enginears and designers can have the appropriate information on hand 
when embarking on new projects. Examples of costly fractures due to poor design or materials selection are much too easy to document. The National Bureau of Standards has established a "Corrosion Data Center" in conjunction with the National Association of Corrosion Engineers. The objective of this center is to provide a central facility for the collection, evaluation and effective dissemination of corrosion data. A computer accessible data base is being constructed to provide such information in tabular or graphical format. To date the topics being addressed are (1) atmospheric corrosion of structural alloys, (2) localized corrosion of stainless steels and other alloys, (3) uniform (general) corrosion of alloys in aqueous and non-aqueous media, and (4) the calculation of potential-pH (Pourbaix) diagrams. The workshop has identified several other areas where such a data base could be extremely usefut, e.g., pitting corrosion, crevice corrosion, corrosion fatigue, stress-corrosion cracking and the use of titanium alloys. As an extension of this concept, in the long term the establishment of so-called expert systems to address corrosion problems would be highly desirable.

\section{Recommendations}

It is recommended that the DOE consider funding $R \& D$ in the area of corrosion control and prevention for energy conservation sytems, and provide funding or support for the establishment of data bases and technology transfer. Initially a modest budget is recommended, and programs should be selected on the basis of the screening criteria used in this report, but also taking into consideration the availability of financial resources in the various sectors. For example, corrosion control and prevention methods have received much attention in the electricity generation and automobile industries. The Electric Power Research Institute exists in the former to sponsor research. However, in other industries, such as the chlor-alkali industry and the pulp and paper industry, there are opportunities for solving major corrosion problems, and thereby conserving energy and materials, but the resources 
are limited. This is particularly true in the former case where production is relatively low and prices are depressed. It is the latter circumstances where the DOE can provide the incentive for conducting the research, particularly when there is a high risk associated with obtaining the desired objectives.

The DOE also can play a supportive role by developing instrumental techniques and testing methodologies, which can be applied to a wide range of corrosion related problems or by focussing on very specific areas, such as molten salt/liquid metal corrosion, and providing a broader perspective to the problem. 


\section{ACKNOWLEDGMENTS}

The authors would like to thank the U.S. Department of Energy, Assistant Secretary for Conservation and Renewable Energy for sponsoring the workshop, which was originally conceived by Dr. Albert R. Landgrebe, Division of Energy Storage. Dr. Landgrebe also provided the direction and financial support necessary to make the workshop a success.

Our thanks are extended also to the workshop particidants for interrupting their busy schedules to contribute to the workshop and help make it a success. Special recognition should be given to Car 1 Locke, Dexter Snyder, Adrian Roberts, Frank McLarnon, Rudy Keller, and Larry Gestaut for competently providing the overviews, some at relatively short notice, in the buildings, transportation and industrial sectors. The efforts of the technical group leaders, Digby MacDonald, Bob Meredith, and Dexter Snyder, certainly were major contributing factors towards attaining the workshop objectives.

The liaison and organizing committees also provided helpful support, and Dick Alkire, Stan Barkin, Richard Spriggs, and Stan Wolf should receive mention in this respect. Others who provided additional support and technical information on specific topics included Warren Berry and Joe Payer (Battelle's Columbis Laboratories); John Bates (Oak Ridge National Laboratory); Henry Leidheiser, Jr. (Lehigh University); Bob Rapp (Ohio State University); Elton Cairns (Lawrence Berkeley Laboratories); Pete McGeer (Alcan); and Jim Doe (ILZRO).

Our appreciation also is extended to Jolene Kitzerow and her associates for handiing the workshop arrangements and logistics at Battelle's Seattle Research Center so capably, and thus enabling the participants to focus on the technical agenda. Finally, thanks are due to Diane Slawson of Battelle's Columbus Laboratories for handling the numerous secretarial needs associated with such an endeavor, and coordinating the preparation of this report. 


\section{BIBLIOGRAPHY}

Given below is a selection of books, reviews, reports, and symposia that contain background information on corrosion; describe the cost of corrosion; provide supporting data or descriptions of work in progress; and identify corrosion problems in selected topic areas.

\section{$\underline{\text { Reports }}$}

(1) "Economic Effects of Metallic Corrosion in the United States", Larry H. Bennett, et al., Special Publ. No. NBS SP 511, National Bureau of Standards, Washington, D.C. (1978).

(2) "Corrosion in Energy Systems", Panel Rept., University of Illinois, Champaign, IL (1979) for OOE, Division of Materials Science.

(3) "Assessment of Research Needs for Advanced Battery Systems", Rept. No. NMAB-390, National Academy Press, Washington, D.C. (1982).

(4) "Fue? Cell Materials Technology in Vehicular Propulsion", Rept. No. MMAB-411, Nationa) Academy Press, Washington, D.C. (1983).

(5) "The Cost of Corrosion and the Need for Research", Robert E. Meredith (1983) for DOE, Office of Systems Research.

(6) "Materials Sciences Prograns: Fiscal Year 1983", Rept. No. DOE/ER-0143/1 (Sept., 1983), DOE, Division of Materials Sciences, Washington, D.C.

(7) "Energy Materials Coordinating Committee (EMACC)", Annual Tech. Rept., Rept. No. 00E/FE0033 (March, 1983), D0E, Washington, D.C.

(8) "Energy Materials Coordinating Committee (EMACC)", Annual Tech. Rept., Rept. No. DOE/CE0078 (March, 1984), D0E, Washington, D.C.

\section{$\underline{\text { Review Papers }}$}

(1) D. D. MacDonald, et a1., "Aqueous Corrosion Problems in Energy Systems", Materials Sci. and Eng., 50 (1981) 19.

(2) R. A. Rapp, et al., "High Temperature Corrosion in Energy Systems", Materials Sci. and Eng., 50 (1981) 1. 
Books

(1) "Corrosion of Metals in Association with Concrete", J. E. Slater, ASTM Spec. Pub1. No. 818, ASTM, Philadelphia, PA (1983).

(2) "Theory of Metallic Corrosion", V. V. Skorchelletti, Leningrad, Russia (1973); Israel Program for Scientific Translations, Jerusalem (1976).

(3) "Coatings for Corrosion Prevention", W. Cochran, D. E. Tonini (Eds.), ASM Materials/Metalworking Technology Series, ASM, Metals Park, $\mathrm{OH}$ (1979).

(4) "Efficient Materials and Coatings Applications for Improved Design and Corrosion Resistance", L. J. Vande Walle (Ed.), ASM Materials/ Metalworking Technology Series, ASM, Metals Park, OH (1981).

(5) "Fundamental Aspects of Corrosion Protection by Surface Modification", E. McCafferty, et al. (Eds.), The Electrochemical Society Inc., Pennington, NJ (1984).

(6) "Electrochemistry in Industry: New Directions", U. Landau, et al. (Eds.), Chap. V: Corrosion; The Aluminum Industry; The Electronics Industry, Plenum Press, New York, NY (1982).

(7) "Corrosion Problems in Energy Conversion and Generation", C. S. Tedmon, Jr. (Ed.), The Electrochemical Society, Inc., Princeton, NJ (1974).

(8) "Corrosion Control by Organic Coatings", H. Leidheiser, Jr. (Ed.), National Association of Corrosion Engineers, Houston, TX (1981).

(9) "Corrosion: Source Book", S. K. Coburn (Ed.), American Society for Metals, Metals Park, OH (1984).

(10) "New Concepts for Coating Protection of Steel Structures", D. M. Berger, R. F. Wint (Eds.), ASTM Special Pub1. No. 841, ASTM, Philadelphia, PA (1984).

(11) "Corrosion Fatigue: Mechanics, Metallurgy, Electrochemistry and Engineering", A. Crooker, B. N. Leis (Eds.), ASTM Special Publ. No. 801, ASTM, Philadelphia, PA (1983).

(12) "Atmospheric Corrosion of Metals", S. W. Dean, Jr., E. C. Rea (Eds.), ASTM Spec. Publ. No. 767, ASTM, Philadelphia, PA (1982).

(13) "Corrosion Causes and Control", M. Henthorne, McGraw-Hill Co., New York, NY (1971-1972), reprinted for Carpenter Technology, Reading, PA. 
(14) "Theoretical Aspects of the Localized Corrosion of Metals", J. Toušek, Trans Tech Publications, Rockport, MD (1985).

(15) "Atmospheric Corrosion", W. H. Ailor (Ed.), Corrosion Monograph Series, The Electrochem. Soc., Inc., John Wiley \& Sons, New York, NY (1983).

(16) "High Temperature Corrosion", R. A. Rapp (Ed.), Publication NACF-6, National Association of Corrosion Engineers, Houston, TX (1983).

(17) "Localized Corrosion--Cause of Metal Failure", M. Henthorne (Ed.) ASTM Special Pubi. No. 516, ASTM, Philadelphia, PA (1972).

(18) "Inderground Corrosion", E. Escalante (Ed.), ASTM Special Publ. No. 741, ASTM, Philadelphia, PA (1981).

(19) "Corrosion by Liquid Metals", J. E. Draley, J. R. Weeks (Eds.), Plenum Press, New York, NY (1970).

(20) "Geothermal Scaling and Corrosion", L. A. Casper, T. R. Pinchbach, (Eds.), ASTM Special Pub1. No. 717, ASTM, Philadelphia, PA (1980).

(21) "Hot Corrosion Problems Associated with Gas Turbines", C. C. Clark (Ed.), ASTM Special Publ. No. 421, ASTM, Philadelphia, PA (1967).

\section{Symposia}

(1) "Corrosion in Energy Conversion Systems", Session A5, 35th Meeting of Int. Soc. of Electrochemistry, Berkeley, CA, August 5-10, 1984.

(2) Gordon Conference on Corrosion, Colby-Sawyer College, July 23-27, 1984, J. C. Scully, Chairman.

(3) "High Temperature Materials and Coatings", Short Course, May 11-18, 1984, Rockville, MD, Continuing Education Inst., N. S. Stoloff, 0. H. Brone, Course Directors.

(4) "Modern Analytical Techniques in Corrosion Research", Short Course, November 26-30, 1984, Materials Research Society, Boston, MA.

(5) "Symposium on Zinc Coated Steel in Building", London, UK, October 12, 1984, British Board of Agrement and British Steel Corporation.

(6) "Industrial Corrosion Problems", Symposium, September 8-10, 1984, Columbus, $\mathrm{OH}$, National Association of Corrosion Engineers, North Centra? Region, J. H. Payer, Chairman.

(7) "Faijure Analysis and Materials Selection for Corrosion Specialists", Short Course, October 7, 1984, New Orleans, LA, The Electrochemical Society, WA, R. H. Jones, Technical Leader. 
(8) "DOE Contractor's Meeting on Localized Corrosion", August 20, 1984, Seattle, WA, R. H. Jones, Technical Leader.

\section{Other Sources of Information}

Appendix B of Reference (5) listed under "Reports" above contains lists of corrosion journals, and other sources of corrosion information apart from public libraries. 
APPENDIX A

WORKSHOP ORGANIZING COMMITTEE

AND LIAISON MEMBERS 
WORKSHOP ON RESEARCH NEEDS FOR CORROSION CONTROL AND PREVENTION IN ENERGY CONSERVATION SYSTEMS

Organizing Committee

Prof. Richard C. Alkire

Department of Chemical Engineering

University of Illinois

1209 West California Street

Jjbana, IL 61801

(217) 333-0063

Dr. Eric w. Brooman (Chairman)

Electrochemical Technology Group

Battelle's Columbus Laboratories

$505 \mathrm{King}$ Avenue

Columbus, $\mathrm{OH} 43201$

(614) $424-5349$

Mr. Jonathan W. Hurwitch (Co-Chairman)

Battelle's Washington Operations

2030 M Street, N.W.

Washington, D.C. 20036

(202) 785-8400

Or. Digby D. Macoonald

Chemistry Department

SRI International

333 Ravenswood Avenue

Menlo Park, CA 94025

(415) $859-3195$

Prof. Robert E. Meredith*

Department of Chemical Engineering

Oregon St:ate University

Corvallis, OR 97331

(503) 754-4831

Dr. Dexter D. Snyder

Electrochemistry Department

General Motors Corporation

Research Laboratories

12 Mile and Mound Roads

Warren, MI 48090

(313) $57.5-3154$
Liaison Members

Dr. Albert R. Landgrebe

Energy Storage Division

U.S. Department of Energy, CE-141

1000 Independence Avenue, S.W.

Washington, D.C. 20585

(202) 252-1483

Dr. E. Neville Pugh

Corrosion Group

National Bureau of Standards

Materials Building, Rm. B-266

Gaithersburg, MD 20899

(301) 921-2094

Dr. Robert J. Reynik

Division of Materials Research

National Science Foundation

Washington, D.C. 20550

(202) 357-9789

Or. Stantey Ruby

Energy Storage Division

U.S. Department of Energy, CE-141

1000 Independence Avenue, S.W.

Washington, D.C. 20585

(202) $252-1486$

Dr. Richard M. Spriggs

National Materials Advisory Board

National Academy of Sciences

2101 Constitution Avenue, N.W.

Washington, D.C. 20418

(202) $334-3489$

Dr. Stanley M. Wolf

Office of Basic Energy Sciences

Materials Sciences Division

U.S. Department of Energy, ER-131

20 Massachusetts Avenue, N.W.

Washington, D.C. 20545

(202) $353-3428$

* Seconded to Energy Storage Division, U.S. Department of Energy, (202) $252-1488$. 



\section{APPENDIX B}

LIST OF WDRKSHOP PARTICIPANTS AND

TECHNICAL GROUP ASSIGNMENTS 
WORKSHOP ON RESEARCH NEEDS FOR CORROSION CONTROL

AND PREVENTION IN ENERGY CONSERVATION SYSTEMS

WORKSHOP PARTICIPANTS

General Corrosion Discussion Group

$\begin{array}{lll}\text { Dexter Snyder } & - & \text { General Motors Corporation (Group Leader) } \\ \text { Brian Barnett } & - & \text { Arthur } 0 . \text { Little } \\ \text { Ed Escalante } & - & \text { National Bureau of Standards } \\ \text { Sid Gross } & - & \text { Boeina Aerospace Company } \\ \text { Carl Locke } & - & \text { University of OKlahoma } \\ \text { Don Shannon } & - & \text { Pacific Northwest Laboratory }\end{array}$

Localized Corrosion Discussion Group

Eric Brsoman

Ted Beck

Larry Gestaut

Hugh I saacs

Phit Russell

Jack Snodgrass
- Battelle's Columbus Laboratories (Group Leader)

- Electrochemical Technology Corporation

- Eltech Systems Corporation

- Brookhaven National Laboratory

- Weyerhaeuser Corporation

- Reynolds Metals

High Temperature Corrosion Discussion Group

Digby MacDonald - SRI International (Group Leader)

Neil Birks - University of Pittsburgh

Frank McLarnon - Lawrence Berkeley Laboratory

Bill Smyrl - University of Minnesota

John Stringer - Electric Power Research Institute

Rudy Keller - EMEC Consultants

Corrosion Control and Prevention Discussion Group

Bob Meredith

Russ Jones

Norman Dison

Adrian Roberts

Neil Thompson

Ravi Varma

Unassigned

Stan Barkin

Jon Hurwitch

A1 Landgrebe

visitor.

Brad Ashton
- Oregon State University (Group Leader)

- Pacific Northwest Laboratory

- Pacific Northwest Laboratory

- Electric Power Research Institute

- Battelle's Columbus Laboratories

- Argonne National Laboratory

- National Academy of Sciences

- Battelle's Washington Operations

- Department of Energy 

APPENDIX C

WORKSHOP AGENDA 
WORKSHOP ON RESEARCH NEEDS FOR CORROSION CONTROL

ANO PREVENTION IN ENERGY CONSERVATION SYSTEMS

Battelle's Seattle Research Center

october 29 - November 1, 1984

Sponsored by:

U.S. Department of Energy

Assistant Secretary for

Conservation and Renewable Energy

Organized by:

Battelle Memorial Institute

\section{FINAL AGENDA}

Time

Event

Location

Monday, October 29, 1984

4:00 p.n.-12:00 p.m. Registration/Check-in

6:00 p..- 9:00 p.m. Welcome Reception

9:00 p.m.-10:00 p.m. Organizing Committee Meeting

Tuesday, October 30,1984

$7: 30-8: 30$
$8: 30-8: 40$

$8: 40-8: 55$

$8: 55-9: 10$
Breakf ast

Welcome - Workshop Organization

J. W. Hurwitch

Workshop Purpose

A. R. Landgrebe

Workshop Objectives

E. W. Brooman
Registration 0esk

Dining $\mathrm{Hall}$

Suite $C-5$

Review of Corrosion Problems
$9: 10-9: 40$
Buildings and Structures
C. E. Locke
$9: 40-10: 10$
Transportation
D. D. Snyder
Lecture Hall
Lecture Hall

Dining Hall

Lecture $\mathrm{Ha} l \mathrm{l}$

Lecture Hall

Lecture $\mathrm{Hall}$ 


\begin{tabular}{|c|c|c|}
\hline $10: 10-10: 25$ & Coffee Break & Seminar Lobby \\
\hline $10: 25-10: 45$ & $\begin{array}{l}\text { Electric Utilities } \\
\text { J. T. A. Roberts }\end{array}$ & Lecture Hall \\
\hline $10: 45-11: 05$ & $\begin{array}{l}\text { Electric-0ther Producers } \\
\text { F. R. McL arnon }\end{array}$ & Lecture Hall \\
\hline $11: 05-11: 25$ & $\begin{array}{l}\text { Industrial Metals } \\
\text { R. Keller }\end{array}$ & Lecture HaIl \\
\hline $11: 25-11: 45$ & $\begin{array}{l}\text { Industrial Chemicals \& Gases } \\
\text { L. J. Gestaut }\end{array}$ & Lecture $\mathrm{Hall}$ \\
\hline $11: 45-11: 50$ & $\begin{array}{l}\text { Technical Group Orientation } \\
\text { E.W. Brooman }\end{array}$ & Lecture $\mathrm{Hall}$ \\
\hline $11: 50-12: 45$ & Lunch & Dining $\mathrm{Hall}$ \\
\hline
\end{tabular}

Technical Group Discussions

\begin{tabular}{|c|c|c|c|}
\hline \multirow{4}{*}{\multicolumn{2}{|c|}{$2: 00-3: 30$}} & $\begin{array}{l}\text { Localized Corrosion } \\
\text { E.W. Brooman - Group Leader }\end{array}$ & Lecture Hall \\
\hline & & $\begin{array}{l}\text { Control and Prevention } \\
\text { R.E. Meredith - Group Leader }\end{array}$ & Conference Room A \\
\hline & & $\begin{array}{l}\text { High Temperature Corrosion } \\
\text { D.D. MacDonald - Group Leader }\end{array}$ & Conference Room B \\
\hline & & $\begin{array}{l}\text { General Corrosion } \\
\text { D. } 0 . \text { Snyder - Group Leader }\end{array}$ & Conference Room C \\
\hline $3: 30$ & $-\quad 3: 45$ & Coffee Break & Seminar Lobby \\
\hline $3: 45$ & $-5: 00$ & $\begin{array}{l}\text { Continue Technical Group } \\
\text { Discussions }\end{array}$ & $\begin{array}{l}\text { Lecture } \mathrm{Hall} \text { and } \\
\text { Conference Rooms } \\
\mathrm{A}, \mathrm{B} \text {, and } \mathrm{C}\end{array}$ \\
\hline $6: 30$ & $-9: 00$ & $\begin{array}{l}\text { Dinner and Informal Discussions } \\
\text { (Transportation departs at } 6 \mathrm{p.m} \text {. } \\
\text { from Registration Desk) }\end{array}$ & $\begin{array}{l}\text { Seattle Center } \\
\text { Space Needle }\end{array}$ \\
\hline \multirow[t]{2}{*}{$9: 30$} & $-10: 30$ & Organizing Committee Meeting & Suite $C-5$ \\
\hline & \multicolumn{3}{|c|}{ Wednesday, October 31,1984} \\
\hline $7: 30$ & $-8: 30$ & Breakf ast & Dining Hall \\
\hline $8: 30$ & $-8: 45$ & $\begin{array}{l}\text { Review of Objectives/Progress } \\
\text { E.W. Brooman }\end{array}$ & Lecture Hall \\
\hline
\end{tabular}




\section{C -3}

\begin{tabular}{|c|c|c|}
\hline $8: 45-10: 15$ & $\begin{array}{l}\text { Continue Technical Group } \\
\text { Discussions }\end{array}$ & $\begin{array}{l}\text { Lecture Hall and } \\
\text { Conference Rooms } \\
\mathrm{A}, \mathrm{B} \text {, and C }\end{array}$ \\
\hline $10: 15-10: 30$ & Coffee Break & Seminar Lobby \\
\hline $10: 30-11: 45$ & $\begin{array}{l}\text { Continue Technical Group } \\
\text { Discussions }\end{array}$ & $\begin{array}{l}\text { Lecture Hall and } \\
\text { Conference Rooms } \\
A, B \text {, and C }\end{array}$ \\
\hline $11: 45-12: 45$ & Lunch & Dining Hall \\
\hline $1: 00-3: 00$ & $\begin{array}{l}\text { Research Priority Ranking } \\
\text { Session }\end{array}$ & $\begin{array}{l}\text { Lecture Hall and } \\
\text { Conference Rooms } \\
\text { A, B, and C }\end{array}$ \\
\hline $3: 00-3: 15$ & Coffee Break & Seminar Lobby \\
\hline $3: 15-5: 15$ & $\begin{array}{l}\text { Integration of Priorities } \\
\text { into Research Plan } \\
\text { E. W. Brooman }\end{array}$ & Seminar Lobby \\
\hline $5: 15-5: 30$ & $\begin{array}{l}\text { Concluding Remarks } \\
\text { A. R. Landgrebe }\end{array}$ & Lecture Hall \\
\hline $6: 30-9: 00$ & Closing Dinner and Discussions & Dining $\mathrm{Hall}$ \\
\hline \multicolumn{3}{|c|}{ Thursday, November 1,1984} \\
\hline $7: 30-8: 30$ & Breakfast & Dining $\mathrm{Ha}\rceil]$ \\
\hline $8: 30-11: 30$ & Organizing Committee Meeting & Lecture Hall \\
\hline $11: 45-12: 45$ & Lunch (optional) & Dining Hall \\
\hline
\end{tabular}



APPENDIX D

RANKING OF RESEARCH NEEDS 
TABLE D-1. RANKING OF RESEARCH NEEDS--GENERAL

CORROSION DISCUSSION GROUP

\begin{tabular}{|c|c|c|}
\hline S ore ${ }^{\star}$ & $\begin{array}{l}\text { Figure of } \\
\text { Merit* }\end{array}$ & Research Need \\
\hline .333 & 81 & $\begin{array}{l}\text { Design, develop a corrosion data base to include effects of } \\
\text { specific environments }\end{array}$ \\
\hline 333 & 54 & Develop "expert systems" on general corrosion \\
\hline 1333 & 54 & $\begin{array}{l}\text { More fundamental studies of the corrosion of steel in } \\
\text { concrete }\end{array}$ \\
\hline .323 & 36 & $\begin{array}{l}\text { Obtain a better understanding of fatigue and stress related } \\
\text { failures on the infrastructure (roads, bridges, etc.) }\end{array}$ \\
\hline 323 & 36 & $\begin{array}{l}\text { Develop new instruments and non-destructive testing methods } \\
\text { to detect general corrosion }\end{array}$ \\
\hline$: 323$ & 36 & $\begin{array}{l}\text { More fundamental studies on automobile corrosion and } \\
\text { protection approaches }\end{array}$ \\
\hline$\vdots 313$ & 27 & Develop less corrosive road de-icer materials \\
\hline$: 313$ & 18 & $\begin{array}{l}\text { Develop models relating corrosion control and protection to } \\
\text { environmental factors }\end{array}$ \\
\hline .323 & 18 & $\begin{array}{l}\text { Obtain a better understanding of the effectiveness of } \\
\text { cathodic protection systems }\end{array}$ \\
\hline 323 & 18 & Develop specifications for government construction projects \\
\hline 313 & 18 & $\begin{array}{l}\text { Evaluate in more detail the impact of the environment on the } \\
\text { corrosion of metals }\end{array}$ \\
\hline$\because 313$ & 18 & Study materials related problems in oil recovery processes \\
\hline$\because 222$ & 16 & $\begin{array}{l}\text { Develop temporary passivation method for calcium battery } \\
\text { electrodes }\end{array}$ \\
\hline$? 222$ & 16 & $\begin{array}{l}\text { Solve corrosion problems with ambient temperature fuel cells } \\
\text { and batteries }\end{array}$ \\
\hline 222 & 8 & Solve materials problems with production and use of synfuels \\
\hline 222 & 8 & Study corrosion aspects of nuclear waste disposal methods \\
\hline
\end{tabular}

* :ee text for details of scoring system. 
TABLE D-2. RANKING OF RESEARCH NEEDS--LOCALIZED

CORROSION DISCUSSION GROUP

\begin{tabular}{|c|c|c|}
\hline Score* & $\begin{array}{l}\text { Figure of } \\
\text { Merit* }\end{array}$ & Research Need \\
\hline 3333 & 81 & $\begin{array}{l}\text { Develop a data base for pitting corrosion and make available } \\
\text { to those who should have the information }\end{array}$ \\
\hline 3333 & 81 & $\begin{array}{l}\text { Develop a data base for crevice corrosion and make available } \\
\text { to those who should have the information }\end{array}$ \\
\hline 3333 & 81 & $\begin{array}{l}\text { Obtain a better understanding of the mechanisms }(s) \text { of crevice } \\
\text { corrosion }\end{array}$ \\
\hline 3333 & 81 & $\begin{array}{l}\text { Study the effect of minor impurities on intergranular } \\
\text { corrosion }\end{array}$ \\
\hline 3332 & 54 & $\begin{array}{l}\text { Evaluate existing and new alloys for their resistance to } \\
\text { corrosion fatigue, and study role of aggressive anions }\end{array}$ \\
\hline 3332 & 54 & $\begin{array}{l}\text { Evaluate use of anodic protection for preventing or control- } \\
\text { ling stress-corrosion cracking }\end{array}$ \\
\hline 3323 & 54 & $\begin{array}{l}\text { Study stress-corrosion cracking of Alloy } 600 \text { in pressurized } \\
\text { water reactor applications }\end{array}$ \\
\hline 3233 & 54 & $\begin{array}{l}\text { Obtain better understanding of localized solution chemistry in } \\
\text { crevice corrosion }\end{array}$ \\
\hline 3233 & 54 & $\begin{array}{l}\text { Establish a corrosion fatigue data base and disseminate } \\
\text { information }\end{array}$ \\
\hline 2233 & 36 & $\begin{array}{l}\text { Develop model and better experimental techniques to study } \\
\text { pitting corrosion of aluminum }\end{array}$ \\
\hline 2323 & 36 & $\begin{array}{l}\text { Solve problem of intergranular corrosion of gas diffusion } \\
\text { electrodes }\end{array}$ \\
\hline 3322 & 36 & $\begin{array}{l}\text { Obtain better data on the intergranular corrosion of Inconel } \\
\mathrm{Ti}, \mathrm{Al} \text {, etc. }\end{array}$ \\
\hline 2323 & 36 & $\begin{array}{l}\text { Determine mechanism(s) of intergranular attack and } \\
\text { contribution if any to stress-corrosion cracking }\end{array}$ \\
\hline 2323 & 36 & $\begin{array}{l}\text { Develop pore-free Ti coatings for dimensionally stable } \\
\text { electrodes }\end{array}$ \\
\hline
\end{tabular}

* See text for details of scoring system. 
TABLE 0-2. (Continued)

\begin{tabular}{|c|c|c|}
\hline s ore & $\begin{array}{l}\text { Figure of } \\
\text { Merit }\end{array}$ & Research Need \\
\hline$? 23$ & 36 & $\begin{array}{l}\text { Develop materials imnune to more than one form of corrosion } \\
\text { attack }\end{array}$ \\
\hline 323 & 36 & $\begin{array}{l}\text { Develop a model to predict, diagnose and prevent stress- } \\
\text { corrosion cracking fajlure }\end{array}$ \\
\hline 223 & 36 & $\begin{array}{l}\text { Determine extent of problem with stress-corrosion cracking in } \\
\text { sour gas wells }\end{array}$ \\
\hline 332 & 36 & $\begin{array}{l}\text { Investigate effect of surface modification by alloying on } \\
\text { crevice corrosion }\end{array}$ \\
\hline 1313 & 27 & Develop a test for detecting corrosion fatigue \\
\hline$: 322$ & 24 & $\begin{array}{l}\text { Study roles of passivation, depassivation and repassivation in } \\
\text { crevice corrosion }\end{array}$ \\
\hline 1223 & 24 & $\begin{array}{l}\text { Study methods to prevent filiform corrosion in photovoltaic } \\
\text { devices }\end{array}$ \\
\hline$\vdots 222$ & 24 & $\begin{array}{l}\text { Develop a test for detecting exfoliation corrosion propensity } \\
\text { for Al alloys }\end{array}$ \\
\hline$: 223$ & 24 & $\begin{array}{l}\text { Study mechanism(s) of cavitation corrosion and develop control } \\
\text { methodology }\end{array}$ \\
\hline$\because 313$ & 18 & Study role of corrosion and fatigue in corrosion fatigue \\
\hline$\because 32$ & 18 & $\begin{array}{l}\text { Obtain a more fundamental understanding of cathodic } \\
\text { protection systems }\end{array}$ \\
\hline 313 & 18 & Study role of fouling in initiating pitting corrosion \\
\hline 233 & 18 & $\begin{array}{l}\text { Provide documentation on effectiveness of cathodic versus } \\
\text { anodic protection to control pitting }\end{array}$ \\
\hline $3 \geq 31$ & 18 & $\begin{array}{l}\text { Study stress-corrosion cracking of Type } 304 \text { stainless steel } \\
\text { boiling water reactors }\end{array}$ \\
\hline 3231 & 18 & Study low temperature chloride cracking of stainless steels \\
\hline 1313 & 18 & Find inhibitors to prevent crevice corrosion \\
\hline
\end{tabular}


TABLE D-2. (Continued)

\begin{tabular}{|c|c|c|}
\hline Score & $\begin{array}{l}\text { Figure of } \\
\text { Merit }\end{array}$ & Research Need \\
\hline 3213 & 18 & Improve resistance of $\mathrm{Ti}$ to exfoliation corrosion \\
\hline 3321 & 18 & $\begin{array}{l}\text { Study effect of relative areas of cathodes and anodes (stee) } \\
\text { rebars) in reinforced concrete structures }\end{array}$ \\
\hline 2213 & 12 & $\begin{array}{l}\text { Study chemistry of localized environments at holidays and } \\
\text { disbonds on coated pipelines and its influence on stress- } \\
\text { corrosion cracking }\end{array}$ \\
\hline 3121 & 6 & $\begin{array}{l}\text { Develop low weight } T i \text { alloys with high resistance to } \\
\text { corrosion fatigue }\end{array}$ \\
\hline 1212 & 4 & $\begin{array}{l}\text { Develop a more resistant alloy than } \mathrm{Ni} 201 \text { for chlor-alkali } \\
\text { evaporators to prevent pitting }\end{array}$ \\
\hline 1221 & 4 & $\begin{array}{l}\text { Develop improved coatings for dimensionally stable } \\
\text { electrodes to prevent pitting corrosion }\end{array}$ \\
\hline 2121 & 4 & $\begin{array}{l}\text { Develop better test methods to detect hard spots in steel to } \\
\text { prevent hydrogen stress cracking }\end{array}$ \\
\hline 1113 & 3 & Find better alloys for aircraft to resist fatigue cracking \\
\hline 1131 & 3 & $\begin{array}{l}\text { Find substitutes for low carbon steel to handle dry, liquid } \\
\text { chlorine without erosion-corrosion }\end{array}$ \\
\hline
\end{tabular}


TABLE 0 -3. RANKING OF RESEARCH NEEDS--HIGH TEMPERATURE CORROSION DISCUSSION GROUP

\begin{tabular}{|c|c|c|}
\hline core* & $\begin{array}{l}\text { Figure of } \\
\text { Merit* }\end{array}$ & Research Need \\
\hline 3233 & 54 & Study mechanism(s) of molten salt corrosion in heat engines \\
\hline 3233 & 54 & $\begin{array}{l}\text { Improve alloys and coatings to resist molten salt corrosion in } \\
\text { heat engines }\end{array}$ \\
\hline 3323 & 54 & $\begin{array}{l}\text { Study mechanism(s) of molten salt corrosion in chemical } \\
\text { processes }\end{array}$ \\
\hline 3323 & 54 & $\begin{array}{l}\text { Study mechanism(s) of molten salt corrosion in fuel cells and } \\
\text { batteries. }\end{array}$ \\
\hline 3323 & 54 & $\begin{array}{l}\text { Study mechanism(s) of molten salt corrosion in electro- } \\
\text { metallurgical processes }\end{array}$ \\
\hline 3323 & 54 & $\begin{array}{l}\text { Study mechanism(s) of molten salt corrosion in heat pipes and } \\
\text { heater elements }\end{array}$ \\
\hline 3322 & 36 & $\begin{array}{l}\text { Develop improved materials to resist molten salt corrosion in } \\
\text { chemical process industries }\end{array}$ \\
\hline 3322 & 36 & $\begin{array}{l}\text { Develop improved materials and coatings for resisting molten } \\
\text { salt corrosion in fuel cells and batteries }\end{array}$ \\
\hline 3322 & 36 & $\begin{array}{l}\text { Improve corrosion resistance of materials to resist molten } \\
\text { salt corrosion in electrometallurgical processes }\end{array}$ \\
\hline 3322 & 36 & $\begin{array}{l}\text { Deve lop improved materials to resist molten salt corrosion for } \\
\text { use in heat pipes and heater elements }\end{array}$ \\
\hline 3232 & 36 & $\begin{array}{l}\text { Develop improved refractories to resist } 1 \text { iquid metal attack in } \\
\text { chemical processes }\end{array}$ \\
\hline 3232 & 36 & $\begin{array}{l}\text { Modify processes to restrict contact between liquid metals and } \\
\text { refractories in chemical processes }\end{array}$ \\
\hline 2233 & 36 & $\begin{array}{l}\text { Develop alloys and coatings for heat engines to resist } \\
\text { erosion-corrosion }\end{array}$ \\
\hline
\end{tabular}

See text for details of scoring system. 
TABLE D-3. (Continued)

\begin{tabular}{|c|c|c|}
\hline Score & $\begin{array}{l}\text { Figure of } \\
\text { Merit }\end{array}$ & Research Need \\
\hline 2233 & 36 & $\begin{array}{l}\text { Develop alloys and coatings for chemical process equidnent } \\
\text { to resist erosion corrosion }\end{array}$ \\
\hline 2223 & 24 & $\begin{array}{l}\text { Deve lop a test methodology to study corrosion by molten salts } \\
\text { in electrometallurgical processes }\end{array}$ \\
\hline 2232 & 24 & $\begin{array}{l}\text { Study mechanism(s) of carburization in chemical orocess } \\
\text { equipment }\end{array}$ \\
\hline 2232 & 24 & Study mechanism(s) of carburization in fue 1 cells \\
\hline 2232 & 24 & $\begin{array}{l}\text { Study mechanism(s) of carburization in other conservation } \\
\text { systems }\end{array}$ \\
\hline 1233 & 18 & Study mechanism(s) of erosion-corrosion in heat engines \\
\hline 1233 & 18 & $\begin{array}{l}\text { Study mechanism(s) of erosion-corrosion in chemical process } \\
\text { equipment such as fluidized bed combustors }\end{array}$ \\
\hline 2222 & 16 & $\begin{array}{l}\text { Study mechanism(s) of erosion-corrosion of cathodes used for } \\
\text { Al electrowinning }\end{array}$ \\
\hline 2222 & 16 & Study mechanism(s) of erosion-corrosion in hypersonic vehicles \\
\hline 1313 & 9 & $\begin{array}{l}\text { Study mechanism(s) of sulfidation in high temperature } \\
\text { batteries and fuel cells }\end{array}$ \\
\hline 1313 & 9 & $\begin{array}{l}\text { Develop materials more resistant to sulfidation for use in } \\
\text { batteries and fuel cells }\end{array}$ \\
\hline 1133 & 9 & $\begin{array}{l}\text { Develop alloys more resistant to mixed oxidants for use in } \\
\text { heat engines }\end{array}$ \\
\hline 1133 & 9 & $\begin{array}{l}\text { Study mechanism(s) of corrosion by mixed oxidants in heat } \\
\text { engines }\end{array}$ \\
\hline 1133 & 9 & $\begin{array}{l}\text { Develop alloys more resistant to mixed oxidants for chemical } \\
\text { process equipment such as incinerators }\end{array}$ \\
\hline 1133 & 9 & $\begin{array}{l}\text { Study mechanism(s) of corrosion by mixed oxidants in chemical } \\
\text { process equipment }\end{array}$ \\
\hline
\end{tabular}


TABLE 0-3. (Continued)

\begin{tabular}{|c|c|c|}
\hline Bcore & $\begin{array}{l}\text { Figure of } \\
\text { Merit }\end{array}$ & Research Need \\
\hline 1133 & 9 & $\begin{array}{l}\text { Develop materials or coatings more resistant to mixed oxidants } \\
\text { for use in batteries and fuel cells }\end{array}$ \\
\hline 1133 & 9 & $\begin{array}{l}\text { Study mechanism(s) of corrosion by mixed oxidants in batteries } \\
\text { and fuel cells }\end{array}$ \\
\hline 1133 & 9 & $\begin{array}{l}\text { Develop alloys more resistant to mixed oxidants for gas } \\
\text { cooled, nuclear reactors }\end{array}$ \\
\hline 1133 & 9 & $\begin{array}{l}\text { Study mechanism(s) of corrosion by mixed oxidants in gas } \\
\text { cooled, nuclear reactors }\end{array}$ \\
\hline 1222 & 8 & $\begin{array}{l}\text { Develop materials resistant to carburization in chemical } \\
\text { process equipment }\end{array}$ \\
\hline 1222 & 8 & $\begin{array}{l}\text { Develop new materials to resist carburization in batteries } \\
\text { and fuel cells }\end{array}$ \\
\hline $122 ?$ & 8 & $\begin{array}{l}\text { Develop materials more resistant to carburization for use in } \\
\text { other conservation system }\end{array}$ \\
\hline 2221 & 8 & $\begin{array}{l}\text { Study mechanisms of carburization of } \mathrm{Al} \text { electrodes in } \mathrm{Ha} M \\
\text { electrowinning cells }\end{array}$ \\
\hline L231 & 6 & $\begin{array}{l}\text { Develop more resistant materials to prevent liquid metal } \\
\text { attack in fuel cells and batteries }\end{array}$ \\
\hline 1122 & 4 & $\begin{array}{l}\text { Find improved materials for use in Al chloride electrowinning } \\
\text { cells }\end{array}$ \\
\hline 1122 & 4 & Study mechanisms of creep and fatigue in heat engines \\
\hline 1122 & 4 & $\begin{array}{l}\text { Study mechanisms of creep and fatigue in structural components } \\
\text { of gasifiers }\end{array}$ \\
\hline 1122 & 4 & $\begin{array}{l}\text { Study mechanisms of creep and fatigue of seals in batteries } \\
\text { and fuel cells }\end{array}$ \\
\hline 1122 & 4 & Study mechanisms of creep and fatigue in nuclear reactors \\
\hline 1122 & 4 & $\begin{array}{l}\text { Develop new materials to resist fretting corrosion in } \\
\text { combustors }\end{array}$ \\
\hline
\end{tabular}


TABLE D-3. (Continued)

\begin{tabular}{|c|c|c|}
\hline Score & $\begin{array}{l}\text { Figure of } \\
\text { Merit }\end{array}$ & Research Need \\
\hline 1122 & 4 & $\begin{array}{l}\text { Develop new materials to resist fretting corrosion in } \\
\text { fluidized bed systems }\end{array}$ \\
\hline 1122 & 4 & $\begin{array}{l}\text { Develop new materials to resist fretting corrosion of fue? } \\
\text { control rods, heat exchangers, etc. in nuclear reactors }\end{array}$ \\
\hline 1121 & 2 & Develop alloys resistant to thermal snalling for heat engines \\
\hline 1121 & 2 & $\begin{array}{l}\text { Deve lop coatings resistant to thermal soalling for heat } \\
\text { engines }\end{array}$ \\
\hline 1121 & 2 & $\begin{array}{l}\text { Find alloys more resistant to oxidation in combustors and } \\
\text { reformers }\end{array}$ \\
\hline 1121 & 2 & $\begin{array}{l}\text { Develop coatings resistant to oxidation in combustors and } \\
\text { reformers }\end{array}$ \\
\hline 1121 & 2 & $\begin{array}{l}\text { Find alloys more resisant to oxidation in batteries and fuel } \\
\text { cells }\end{array}$ \\
\hline 1121 & 2 & $\begin{array}{l}\text { Develop coatings to resist oxidation in batteries and fuel } \\
\text { cells }\end{array}$ \\
\hline 1121 & 2 & $\begin{array}{l}\text { Develop more resistant alloys for anodes and sensors in A1 } \\
\text { electrowinning }\end{array}$ \\
\hline 1121 & 2 & $\begin{array}{l}\text { Develop coatings to resist oxidation for anodes and sensors } \\
\text { in Al electrowinning }\end{array}$ \\
\hline 1121 & 2 & $\begin{array}{l}\text { Develop alloys to resist oxidation in other conservation } \\
\text { systems }\end{array}$ \\
\hline 1121 & 2 & $\begin{array}{l}\text { Develop coatings to resist oxidation in other conservation } \\
\text { systems }\end{array}$ \\
\hline 1121 & 2 & $\begin{array}{l}\text { Find improved materials to resist sulfidation in chemical } \\
\text { process equipment }\end{array}$ \\
\hline 1112 & 2 & $\begin{array}{l}\text { Study mechanism(s) of liquid metal attack in sodium heat } \\
\text { engines }\end{array}$ \\
\hline 1112 & 2 & Study wetting by liquid metals in sodium engines \\
\hline 1121 & 2 & $\begin{array}{l}\text { Study mechanism(s) of fretting corrosion in advanced heat } \\
\text { engine concepts }\end{array}$ \\
\hline
\end{tabular}


TABLE D-3. (Continued)

\begin{tabular}{lll}
1121 & $\begin{array}{c}\text { Figure of } \\
\text { Merit }\end{array}$ & $\begin{array}{l}\text { Study mechanism(s) of fretting corrosion in fluidized bed } \\
\text { systems }\end{array}$ \\
1121 & 2 & $\begin{array}{l}\text { Study mechanism(s) of fretting corrosion of control rods, in } \\
\text { heat exchangers, etc., in nuclear reactors } \\
\text { Develino alloys resistant to sulfidation for sulfur vapor } \\
\text { engines } \\
\text { Develop improved materials to resist chloride attack in dry } \\
\text { chlorine gas streams }\end{array}$ \\
\hline$: 111$ & 1 & 1
\end{tabular}


TABLE D-4. RANKING OF RESEARCH NEEDS--CORROSION CONTROL AND PREVENTION DISCUSSION GROUP

\begin{tabular}{|c|c|c|}
\hline Score* & $\begin{array}{l}\text { Figure of } \\
\text { Merit* }\end{array}$ & Research Need \\
\hline 3323 & 54 & $\begin{array}{l}\text { Develop alloys which conserve strategic materials and increase } \\
\text { the use of ferritic and martensitic stainless steels }\end{array}$ \\
\hline 3332 & 54 & $\begin{array}{l}\text { Develop criteria for cathodically protecting specific } \\
\text { structures, such as bridge decks }\end{array}$ \\
\hline 3332 & 54 & $\begin{array}{l}\text { Expand the use of anodic protection to control microbiological } \\
\text { corrosion and stress-corrosion cracking }\end{array}$ \\
\hline 3322 & 36 & $\begin{array}{l}\text { Develop electrochemical instrumentation for failure analysis } \\
\text { and detection }\end{array}$ \\
\hline 3322 & 36 & Find less corrosive de-icers for highway use \\
\hline 3223 & 36 & $\begin{array}{l}\text { Study effect of trace amounts of contaminants on cracking } \\
\text { phenomena and develop removal methods }\end{array}$ \\
\hline 3331 & 27 & $\begin{array}{l}\text { Increase the data base for use of } \mathrm{Ti} \text { alloys as substitutes for } \\
\text { highly alloyed stainless steels and nickel alloys }\end{array}$ \\
\hline 3331 & 27 & $\begin{array}{l}\text { Provide technology transfer for existing methods to new } \\
\text { applications }\end{array}$ \\
\hline 3331 & 27 & $\begin{array}{l}\text { Provide technology transfer on the correct use of materials } \\
\text { and their substitution }\end{array}$ \\
\hline 1323 & 18 & $\begin{array}{l}\text { Use surface modification techniques to develop low cost. } \\
\text { corrosion resistant materials or coatings }\end{array}$ \\
\hline 1323 & 18 & $\begin{array}{l}\text { Develop in situ techniques for detection and measurement of } \\
\text { crack growth }\end{array}$ \\
\hline 2231 & 12 & $\begin{array}{l}\text { Increase the data base for the use of stabilized stainless } \\
\text { steels such as Type } 347\end{array}$ \\
\hline
\end{tabular}

* See text for details of scoring system. 


\section{DISTRIBUTION}

Ho. of

Copies

:HFSITE

$\therefore \quad$ Mr. U. Ouinn

11.S. Department of Energy

Forrestal Building, Rm 6 A049

lou Independence Ave., SW

liashington, bC 20585

i!l Mr. A. R. Landgrebe

II.S. Department of Energy

Electrochenical Energy Storaye

CE- 1.1 , MS 5 E-036

Forrestal Building

10 int? Independence Ave., 5 W

lashington, oc 20585

3.) Dile rechnical Information

center

i). J. Birk

Flectric Power Research Institute

$3+12$ Hillview Ave.

Pl) $30 \times 1041$ ?

Palo Alto, CA 94303

Mr. J. Rrogan

(I.S. Department of Energy

iffice of Energy Systeris

Research

Forrestal Building, Rn 5E-052

1000 Independence Rve., SW

liasrington, bC 20585

Pr. P. Brown

I.S. Department of Energy

Forrestal Building

ljon Independence Rve., SW

vasilington, DC 20585
No. of

Sopies

Dr. E. Cairns

Lawrence Berkeley Laboratory

Energy and Environment Division

One Cyclotron Road

Building 90, 3rd Floor

Berkeley, CA 94720

Dr. R. P. Clark

Sandia National Laboratories

PO Box 5800

Alhuquerque, NM 87185

Dr. T. Farreli

U.S. Department of Energy

Electrochemical Energy Storage

Forrestal Building

CE-141, MS S E-036

1000 Independence Ave., Sw

Washington, DC 20585

Mr. M. Chiogigio

U.S. Department of Energy

Forrestal Building, Rm 6A049

1000 Independence Ave., SW

Washington, $\mathrm{nC} 20585$

Mr. K. Grothaus

Sandia National Laboratory

Kirtland Air Force Base

P0 Box 5800

Albuquerque, NM 87185

Mr. F, R. Kalhammer

Electric Power Research Institute

3412 Hillview Ave.

PO Box 10412

Palo Alto, CA 94303 
No. of

Copies

Dr. K. Kinoshita

Lawrence Berkeley Laboratory

Energy and Environment Division Building 90, 3rd Floor Rm 3026

Berkeley, CA 94720

Mr. R. Kirk

U.S. Department of Energy

Office of Vehicle and

Engineering R\&D

1000 Independence Ave., Sh

washington, DC 20585

Dr. F. McLarnon

Lawrence Berkeley Laboratory

Building 90, Room 3026

Berkeley, CA 94720

Dr. N. J. Magnani

Sandia National Laboratories

P0 Box 5800

Albuquerque, NM 87185

Mr. R. Matsumoto

Ceramatec, Inc.

163 west 1700 South

Salt Lake City, UT 84115

Dr. R. Meredith

U.S. Departiment of Energy

Electrochemical Energy Storage

Forrestal Building

CE-141, 115 5 E-036

1000 Independence Ave., SW

Washington, DC 20585

Dr. E. Brooman

$505 \mathrm{King}$ Avenue

Columbus, $\mathrm{OH} 43201$
ONS ITE

DOE - Richland Operations

H. E. Ransom

153 Pacific Northwest Laboratory

W. B. Ashton

D. R. Brown

R. M. Fleischinan

C. J. Hostick

J. Hurwitch

C. H. Imnoff (141)

Publishing Coordination (2)

Technical Information (5) 